\title{
Intracellular Calcium and Cell Death during Ischemia in Neonatal Rat White Matter Astrocytes In Situ
}

\author{
Robert Fern \\ Department of Neurology, University of Washington, Seattle, Washington 98195
}

The major pathological correlate of cerebral palsy is ischemic injury of CNS white matter. Histological studies show early injury of glial cells and axons. To investigate glial cell injury, I monitored intracellular $\mathrm{Ca}^{2+}$ and cell viability in fura-2-loaded neonatal rat white matter glial cells during ischemia. Fura-2 fixation combined with immunohistochemistry revealed that fura-2-loaded cells were $\mathrm{GFAP}^{+} / \mathrm{O}^{-}$and were therefore a population of neonatal white matter astrocytes.

Significant ischemic $\mathrm{Ca}^{2+}$ influx was found, mediated by both $\mathrm{L}-$ and T-type voltage-gated $\mathrm{Ca}^{2+}$ channels. $\mathrm{Ca}^{2+}$ influx via T-type channels was the most important factor during the initial stage of ischemia and was associated with significant cell death within 10-20 min of the onset of ischemia. The $\mathrm{Na}^{+}-$

Prolonged perinatal anoxia-ischemia can produce extensive CNS injury, in particular within white matter structures of the brain (Banker and Larroche, 1962; Paneth et al., 1994; Volpe, 1995). This pattern of injury (periventricular leukomalacia) is the major neurological lesion associated with cerebral palsy, a disorder affecting $\sim 2$ per 1000 live births (Kuban and Leviton, 1994). Periventricular leukomalacia is characterized by early damage of axons and glial cells (Gilles and Murphy, 1969; Leviton and Gilles, 1971; Banker and Larroche, 1974; Paneth et al., 1994; Volpe, 1995). There is subsequent microglial activation and astrocyte proliferation, followed by cavitation (Banker and Larroche, 1974; Paneth et al., 1994). Considering the role that glia play in normal CNS development (Racik, 1981), the early glial cell injury may be seminal in the development of the lesion. An ultimate reduction in oligodendrocyte numbers has been taken to indicate that the initial glial cell injury is restricted mainly to oligodendrocytes (Oka et al., 1993; Volpe, 1995). However, no information exists regarding the sensitivity of neonatal white matter astrocytes to ischemia, although astrocyte injury has been reported in periventricular leukomalacia (see Paneth et al., 1994).

In neurons, ischemic injury is mediated by $\mathrm{Ca}^{2+}$ influx through voltage- and receptor-gated ion channels (Choi, 1988; Siesjo and Bengtsson, 1989). Astrocytes also express a number of voltageand receptor-gated ion channels that could act as pathways for $\mathrm{Ca}^{2+}$ influx during ischemia (Barres et al., 1990; Corvalan et al., 1990; Kriegler and Chiu, 1993; Sontheimer, 1994; Gallo and Russell, 1995; Verkhratsky et al., 1998). Anoxic injury of cultured

\footnotetext{
Received May 4, 1998; revised June 22, 1998; accepted June 30, 1998.
}

This work was supported by Grant NS36790-01 from the National Institute of Neurological Diseases and Stroke. I thank Dr. T. Möller for help with immunostaining; I also thank R. Wender and Drs. J. S. Roberts, A. M. Brown, and T. Möller for comments on this manuscript.

Correspondence should be addressed to Dr. Robert Fern, Department of Neurology, University of Washington, Box 356465, Seattle, WA 98195.

Copyright (C) 1998 Society for Neuroscience $\quad 0270-6474 / 98 / 187232-12 \$ 05.00 / 0$
$\mathrm{Ca}^{2+}$ exchanger acted to remove cytoplasmic $\mathrm{Ca}^{2+}$ throughout the ischemic and recovery periods. Neither the release of $\mathrm{Ca}^{2+}$ from intracellular stores nor influx via glutamate-gated channels contributed to the rise in intracellular $\mathrm{Ca}^{2+}$ during ischemia. Ischemic cell death was reduced significantly by removing extracellular $\mathrm{Ca}^{2+}$ or by blocking voltage-gated $\mathrm{Ca}^{2+}$ channels. The exclusively voltage-gated $\mathrm{Ca}^{2+}$ channel nature of the $\mathrm{Ca}^{2+}$ influx, the role played by T-type $\mathrm{Ca}^{2+}$ channels, the protective effect of the $\mathrm{Na}^{+}-\mathrm{Ca}^{2+}$ exchanger, and the lack of significant $\mathrm{Ca}^{2+}$ release from intracellular stores are features of ischemia that have not been reported in other CNS cell types.

Key words: axon; astrocyte; cerebral palsy; glia; ischemia; nerve fiber; white matter

astrocytes is partly dependent on $\mathrm{Ca}^{2+}$ influx via L-type voltagegated $\mathrm{Ca}^{2+}$ channels (Yu et al., 1989; Haun et al., 1992; Pappas and Ransom, 1995), whereas the importance of other routes of $\mathrm{Ca}^{2+}$ entry remains unclear even in this reduced preparation. $\mathrm{Ca}^{2+}$ influx during ischemia has been reported in immature gray matter astrocytes in situ (Duffy and MacVicar, 1996). $\mathrm{Ca}^{2+}$ influx is mediated at least partly through voltage-gated channels, but its significance for cell viability is not known.

To investigate the mechanisms of $\mathrm{Ca}^{2+}$ influx and cell death that may operate in astrocytes during periventricular leukomalacia requires a methodology that is based on ischemia of in situ neonatal white matter astrocytes. Astrocytes in the neonatal rat optic nerve (nRON; a CNS white matter tract) were loaded with the $\mathrm{Ca}^{2+}$-sensitive dye fura-2, and various potential routes of ischemic $\mathrm{Ca}^{2+}$ entry were investigated. Simultaneously, astrocyte cell death was quantitated by assessing the ability of the cells to retain dye. Ischemic $\mathrm{Ca}^{2+}$ rises were found in all cells and were associated with cell death. The $\mathrm{Ca}^{2+}$ rises were a product of $\mathrm{Ca}^{2+}$ influx rather than the release of $\mathrm{Ca}^{2+}$ from intracellular stores. $\mathrm{Ca}^{2+}$ influx was mediated via $\mathrm{L}$ - and T-type voltage-gated $\mathrm{Ca}^{2+}$ channels and not by glutamate receptors. The $\mathrm{Na}^{+}-\mathrm{Ca}^{2+}$ exchanger acted to export $\mathrm{Ca}^{2+}$ from the cytoplasm in the ischemic and postischemic periods. Many of these features of ischemia are unique to neonatal white matter astrocytes among the cells that have been studied.

\section{MATERIALS AND METHODS}

Dye loading. Optic nerves were dissected from postnatal (P) P0-P2 Long-Evans rats and placed in artificial CSF (aCSF) composed of (in mм) $153 \mathrm{NA}^{+}, 3 \mathrm{~K}+, 2 \mathrm{Mg}^{2+}, 2 \mathrm{Ca}^{2+}, 131 \mathrm{Cl}^{-}, 26 \mathrm{HCO}_{3}^{-}, 2 \mathrm{H}_{2} \mathrm{PO}_{4}^{-}$, and 10 glucose. A stock solution containing $1 \mathrm{~mm}$ fura-2 AM (Molecular Probes, Eugene, OR) was made in dry DMSO and $10 \%$ pluronic acid. Seven microliters of the stock were added to $1 \mathrm{ml}$ of aCSF to give a final fura-2 AM concentration of $7 \mu \mathrm{M}$, which was used for all incubations. A variety of different incubation protocols were assessed for fura-2 AM loading of the cells in the optic nerve. It was found that a $20 \mathrm{~min}$ period 
of exposure to collagenase $(200 \mathrm{U} / \mathrm{ml}$ collagenase type I; Sigma, St. Louis, MO) was required to achieve adequate dye accumulation in cells. Presumably, the enzyme disrupted the connective tissue, allowing dye to penetrate into the tissue. nRONs were incubated for $20 \mathrm{~min}$ at $37^{\circ} \mathrm{C}$ in aCSF containing $7 \mu \mathrm{M}$ fura-2 AM, collagenase, and a trace amount of EGTA. Then nerves were transferred to fresh aCSF and $7 \mu \mathrm{M}$ fura-2 AM for $60 \mathrm{~min}$ at room temperature. The nerves were maintained in hydrated $95 \% \mathrm{O}_{2} / 5 \% \mathrm{CO}_{2}$ atmosphere for both incubation periods. The nerves were washed in aCSF before being mounted in the perfusion chamber.

Imaging set-up. The ends of the optic nerves were fixed to a $22 \times 44$ mm glass coverslip with small amounts of cyanoacrylate glue, leaving the majority of the nerve completely free of glue. The coverslip was sealed onto a Plexiglas perfusion chamber (atmosphere chamber, Warner Instruments, Hamden, CT) with silicone grease. aCSF was run through the chamber at a rate of $2-3 \mathrm{ml} / \mathrm{min}$, with a fluid level of $\sim 1 \mathrm{~mm}$ completely covering the nerve. The top of the chamber was sealed with a second coverslip, and $95 \% \mathrm{O}_{2} / 5 \% \mathrm{CO}_{2}$ was blown over the aCSF at a rate of 1.5 $1 / \mathrm{min}$. The chamber had a two-compartment design. The nerve was located in the center of the larger chamber, which contained a fluid volume of $\sim 0.5 \mathrm{ml}$ and had a lozenge shape to minimize fluid turbulence. This chamber was connected to a second, smaller chamber from which the aCSF was sucked under vacuum. aCSF was bubbled with $95 \% \mathrm{O}_{2} / 5 \%$ $\mathrm{CO}_{2}$, kept in a water bath at $\sim 40^{\circ} \mathrm{C}$, and run through Tygon plastic tubing (Norton, $\mathrm{OH}$ ) that was copper-clad to minimize gas exchange. A star valve with a purge system was used to achieve a bath dye washout of $\sim 1 \mathrm{~min}$.

The chamber was mounted on the stage of a Nikon Diaphot-TMD inverted epifluorescence microscope (Tokyo, Japan) equipped with a $40 \times$ fluorescence oil objective (Dapo 40 UV; Olympus, Tokyo, Japan). Chamber temperature was maintained closely at $37^{\circ} \mathrm{C}$ with a flowthrough feedback tubing heater (Warner Instruments, Hamden, CT) positioned immediately before the aCSF entered the chamber; a feedback stage heater (Warner Instruments), which heated the metal surround holding the chamber; and a feedback objective heater (Bioptechs, Butler, PA), which warmed the objective to $37^{\circ} \mathrm{C}$. This combination of heating systems regulated the temperature of the bath and coverslip to $37^{\circ} \mathrm{C}$, as established periodically with a temperature probe.

Cells within the optic nerve were visualized with a Hamamatsu C2400 intensified charge-coupled device (ICCD) video camera and image intensifier system (Hamamatsu, Bridgewater, NJ). Data were collected and stored with an image acquisition program from Photon Technology (East Brunswick, NJ) running on a Dell 486-Omniplex personal computer (Austin, TX). It was found that the preparation shifted slightly during the relatively long recording period of the experiments. For this reason the data were converted to tagged image file format (TIFF) format after the experiment and transferred to a Macintosh Power PC for off-line analysis. The data were analyzed with National Institutes of Health IMAGE software (National Institutes of Health, Bethesda, MD), which allowed the region of interest (ROI) drawn around each cell to be moved between frames. The size and shape of the ROIs were not changed at any point for any given cell.

Experimental protocol. Once mounted in the microscope, the optic nerves were left to equilibrate for $20 \mathrm{~min}$. Then a $5 \mathrm{~min}$ period of baseline was taken before switching to ischemic conditions. Ischemia was induced by changing from aCSF to perfusion with zero-glucose aCSF that had been bubbled with $95 \% \quad \mathrm{~N}_{2} / 5 \% \mathrm{CO}_{2}$ for at least $1 \mathrm{hr}$. The atmosphere in the recording chamber was switched simultaneously to $95 \% \mathrm{~N}_{2} / 5 \% \mathrm{CO}_{2}$. Ischemia was maintained for $80 \mathrm{~min}$, at which point normal conditions were reestablished for a further $60 \mathrm{~min}$ of recovery. Cells initially were brought into focus during illumination at $360 \mathrm{~nm}$. A field of between 10 and 70 cells was typical. Then the nerves were illuminated at 340,360, and $380 \mathrm{~nm}$, and images were collected at 520 $\mathrm{nm}$. This series was collected every $5 \mathrm{~min}$, with four to eight frames averaged per excitation wavelength. This low recording frequency was used to minimize any deleterious effects of illumination on the cells and to limit dye bleaching over the long recording times that were used. Changes in the 340:380 ratio were taken to indicate changes in intracellular $\mathrm{Ca}^{2+}$ concentration $\left(\left[\mathrm{Ca}^{2+}\right]_{\mathrm{i}}\right)$ (Grynkiewicz et al., 1985). Because the majority of cells died during ischemia, it was not possible to calibrate the ratio signal to give accurate values of $\left[\mathrm{Ca}^{2+}\right]_{\mathrm{i}}$.

Cell death. The 360 signal was monitored to assess the capacity of cells to retain dye. The isosbestic ( $\mathrm{Ca}^{2+}$-insensitive) wavelength was used to eliminate the possibility that signal changes were attributable to alterations in $\left[\mathrm{Ca}^{2+}\right]_{\mathrm{i}}$. Sudden and irreversible loss of 360 signal from a cell such that the fluorescence fell to the background level correlated with the breakdown of cell membrane integrity and the release of dye into the extracellular space (Lemasters et al., 1987; Geeraerts et al., 1991). Loss of cell membrane integrity was taken to indicate cell death. The principle is identical to dye exclusion techniques such as propidium iodide staining. In both cases, cell membrane integrity is assessed by its permeability to a lipophobic dye. The use of intracellular fluorescent dye for quantitating cell death has been described in detail (Bevensee and Boron, 1995), and fura-2 has been used in this way in previous studies (Johnson et al., 1994; Pappas and Ransom, 1995). Because of the slow shifting of the preparation, cells occasionally were refocused during experiments. Even so, a small proportion of cells drifted out of the focal plane of the remaining cells and therefore were discarded. This event was distinct from cell death and was characterized by the slow fading of the cell, the 360 signal drifting down over the course of the experiment.

Immunohistochemistry. The lineage of fura-2-loaded cells was investigated immunohistologically. In sample nRONs that had been subjected to the normal dye-loading protocol, fura-2 was fixed in the tissue with 1-ethyl-3-(3-dimethylaminopropyl) carbodiimide (EDC). EDC (40 mg/ $\mathrm{ml}$ ) in aCSF for $90 \mathrm{~min}$ was found to provide excellent dye fixation (Tymianski et al., 1997). Then the nerves were washed in PBS containing $3 \%$ fetal bovine serum (FBS) and $0.1 \mathrm{~m}$ glycine for $10 \mathrm{~min}$ before being permeabilized with $1 \%$ Triton X-100 in PBS for $40 \mathrm{~min}$. The nerves were washed in $3 \%$ FBS in PBS for 10 min before overnight incubation in $3 \%$ FBS in PBS with a primary antibody. Monoclonal antibodies raised against glial fibrillary acidic protein (GFAP, 1:3; Boehringer Mannheim, Indianapolis, IN) and O4 (1:5; Boehringer Mannheim) were used. The nerves were washed in $3 \% \mathrm{FBS}$ in PBS for $2 \mathrm{hr}$ before incubation with secondary antibody (Cy3, 1:30; Sigma) for $3.5 \mathrm{hr}$. The nerves were mounted in a Bio-Rad MRC-1024 UV confocal microscope (Hercules, $\mathrm{CA})$, and fura-2 and Cy3 images were collected simultaneously.

Statistics. Results are reported as mean \pm SEM. Means represent the values of all cells studied under a particular condition (cells from all of the nerves were pooled). SEM represents the standard error of the mean values between nerves (cells pooled within nerves; error calculated between nerves). Data from P0 and P2 nerves were found to be not significantly different. Statistical significance was determined by ANOVA, with Tukey's post-test.

\section{RESULTS}

\section{Cell identification}

The lineage of fura-2-loaded cells in the nRON was investigated immunohistochemically. Fura-2 was fixed in normal dye-loaded optic nerves with the water-soluble reagent EDC (see Tymianski et al., 1997) and subsequently was processed for O4 or GFAP immunostaining. $\mathrm{Cy} 3$ was used as the secondary antibody because it has excitation/emission characteristics distinct from those of fura- 2 and because it has a high quantal efficiency. Fura-2 in optic nerves was excited at $364 \mathrm{~nm}$, and images were collected at 520 $\mathrm{nm}$; Cy3 was excited at $550 \mathrm{~nm}$ with images collected at $565 \mathrm{~nm}$. A typical set of confocal images from a GFAP-stained nerve are shown in Figure 1.

Significant GFAP staining was found throughout the optic nerve. GFAP ${ }^{+}$somata were noted near the outer edge of the tissue, and $\mathrm{GFAP}^{+}$elements ramified throughout the nerve interior (Fig. 1, top left). Fura-2 was present within the GFAP ${ }^{+}$ somata (Fig. 1, top right), and combined images showed that all $\mathrm{GFAP}^{+}$cells in this section of the nerve contained fura-2 (Fig. 1, bottom). In fact, all of the large numbers of cells in the two optic nerves examined that contained fura- 2 were GFAP ${ }^{+}$. It appeared from Figure 1 that GFAP-reactive processes within the nerve also might contain fura-2, but the resolution was not adequate to prove this point. It is clear, however, that fura-2 loading into cell bodies far exceeded dye loading into astrocyte cell processes or axons. $\mathrm{No} \mathrm{O}_{4}{ }^{+}$cells were found in $\mathrm{P} 0-\mathrm{P} 2$ nerves, although $\mathrm{O} 4{ }^{+}$ cells were observed in P8 nerves used as a positive control (data not shown). 

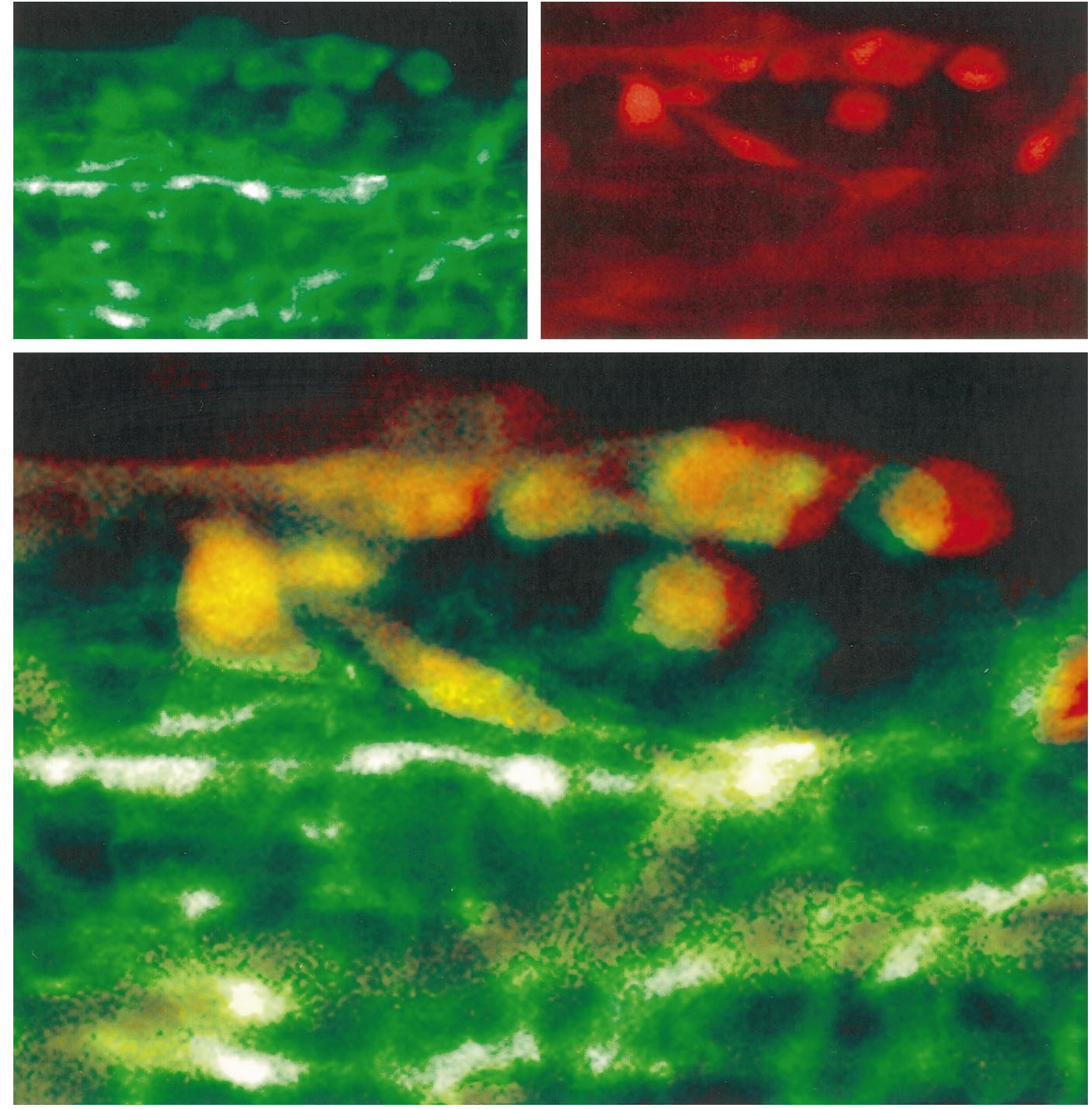

Figure 1. Colocalization of GFAP and fura- 2 in the nRON. Top left, Confocal image of GFAP immunoreactivity in a P1 RON. Cy3 secondary antibody was excited at $550 \mathrm{~nm}$, and the image was collected at $565 \mathrm{~nm}$. This slice was taken at the edge of the nerve (oriented at the top of the panel), showing a number of $\mathrm{GFAP}^{+}$so- $^{-}$ mata. Top right, Confocal image of fura- 2 in the same section as the top left panel. Fura-2 was excited at 364 $\mathrm{nm}$, and the image was collected at 520 nm. Bottom, Superimposed images from the top panels, showing that all cells containing fura- 2 are GFAP ${ }^{+}$.

\section{Ischemia}

The onset of ischemia was followed by an increase in the 340:380 ratio in all cells (397 cells, 10 nerves). The majority of cells exhibited a precipitous loss of dye at some point either during ischemia or during recovery, correlating with cell death. A series of 360 images of an optic nerve at different times during an ischemia experiment is shown in Figure 2 (left). Initially, there were six cells within this region of the nerve (marked 1-6 in the line drawing to the right, Fig. 2). At various points three of the six cells disappeared from the images. For example, cell 1 was present at $0 \mathrm{~min}$ and $20 \mathrm{~min}$, but not at $25 \mathrm{~min}$. The $340: 380$ ratio of the three cells that died in this manner is shown in Figure $2 A$, and the 360 intensity is shown in Figure $2 B$. The values have been shifted along the $y$-axis to differentiate the three plots more clearly. $\left[\mathrm{Ca}^{2+}\right]_{\mathrm{i}}(340: 380$ ratio) started to increase within 5-10 min of the onset of ischemia in all three cells. In cell $1,\left[\mathrm{Ca}^{2+}\right]_{\mathrm{i}}$ reached a peak after $20 \mathrm{~min}$, and the 360 intensity was fairly stable up to that point. At $25 \mathrm{~min}$ the 360 intensity collapsed to the background level and stayed at that level for the rest of the experiment. The 340:380 ratio became meaningless at that point, because it reflected the ratio of the background fluorescence. The two other cells showed similar behavior, with $\left[\mathrm{Ca}^{2+}\right]_{\mathrm{i}}$ rising before eventual cell death.

The incidence of cell death during ischemia is shown in Figure $3 A$. The percentage of the initial total number of cells that died in any given 5 min epoch was plotted against time. The onset of ischemia was followed by a wave of cell death that peaked between 20 and $35 \mathrm{~min}$, with significant cell death continuing through the period of ischemia. Cell death also occurred during the recovery period. In all, $46.6 \%$ of the cells died during the period of ischemia (179 of 397 cells, 10 nerves), and $59.5 \pm 5.2 \%$ of the cells died over the entire $145 \mathrm{~min}$ period of the experiment (236 of 397 cells) (Figs. 3A, 12). There was some cell death in control experiments in which nerves were perfused continually with normal oxygenated aCSF (Figs. 3B, 12). Under these conditions, $13.3 \pm 4.5 \%$ of the cells died in $145 \mathrm{~min}$ of recording (21 of 161 cells, 4 nerves).

\section{$\mathrm{Ca}^{2+}$ influx during ischemia}

Cell death and changes in $\left[\mathrm{Ca}^{2+}\right]_{\mathrm{i}}$ during ischemia were dependent on the presence of extracellular $\mathrm{Ca}^{2+}$. Astrocytes in nerves perfused with aCSF that contained $50 \mu \mathrm{M}$ EGTA and no $\mathrm{Ca}^{2+}$ had stable $\left[\mathrm{Ca}^{2+}\right]_{\mathrm{i}}$ during $80 \mathrm{~min}$ ischemia experiments (Fig. 4A). In all, $25.5 \pm 2.7 \%$ of the cells died under these conditions, significantly less than ischemia experiments performed in the presence of $\mathrm{Ca}^{2+}$ (55 of 216 cells, 3 nerves; $p<0.001$ ) (Figs. $4 D$, 12). This degree of cell death was, however, higher than that found under control conditions in the absence of ischemia (25.4 \pm $2.7 \%$ as compared with $13.3 \pm 4.5 \%$, respectively; $p<0.05$ ). Cell death was not preceded by an increase in $\left[\mathrm{Ca}^{2+}\right]_{\mathrm{i}}$ within the $5 \mathrm{~min}$ 

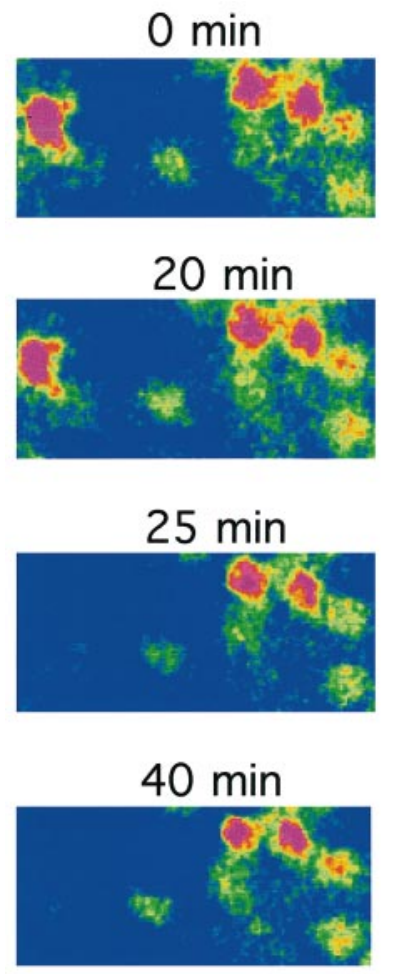

Figure 2. Ischemia is followed by increased $\left[\mathrm{Ca}^{2+}\right]_{\mathrm{i}}$ and cell death in neonatal white matter astrocytes. Left, A series of 360 images of a section of nRON taken at various times after the onset of ischemia. Six cells are clearly visible at $t=0 \mathrm{~min}$ (shown in a line drawing, top right). At different points during ischemia three of the cells disappear from the images. $A$, The change in 340:380 ratio of cells 1,2 , and 3 , showing that ischemia results in increases in $\left[\mathrm{Ca}^{2+}\right]_{\mathrm{i}}$. Filled symbols indicate that the cell retained dye; open symbols indicate that the cell died and no longer retained dye. $B$, The 360 intensity of the cells, showing loss of signal at different times after the onset of ischemia. Loss of fluorescence was taken to indicate cell death, and the 340:380 ratio no longer represented $\left[\mathrm{Ca}^{2+}\right]_{\mathrm{i}}$ after that point. Note that plots have been shifted along the $y$-axis to differentiate the data more clearly.

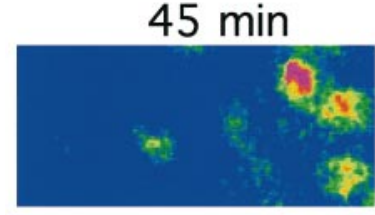

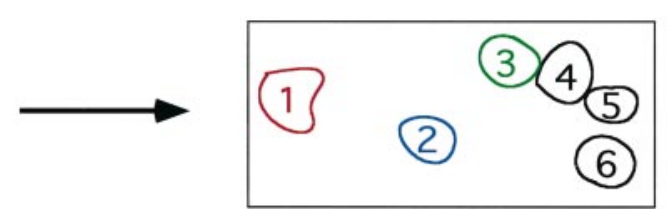

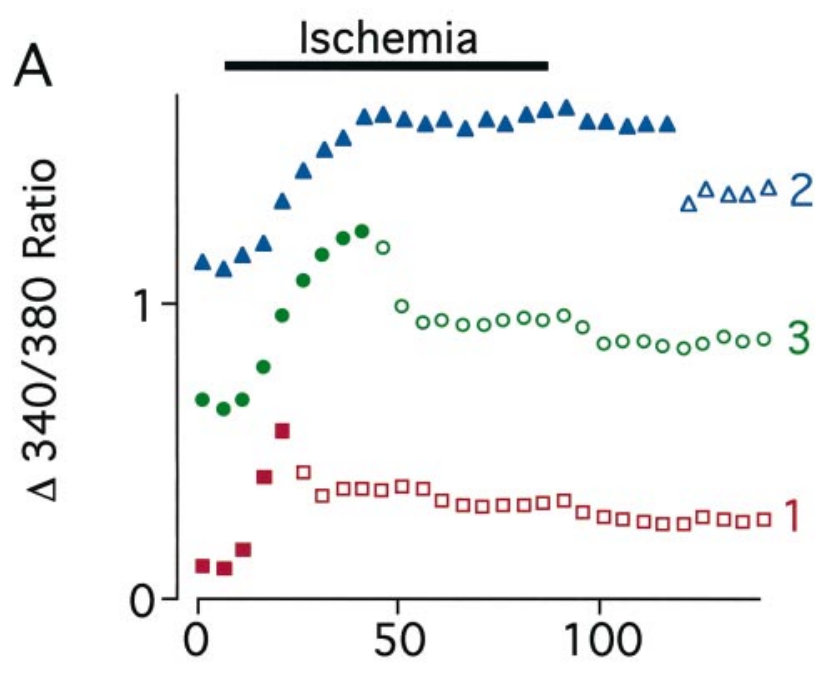

B

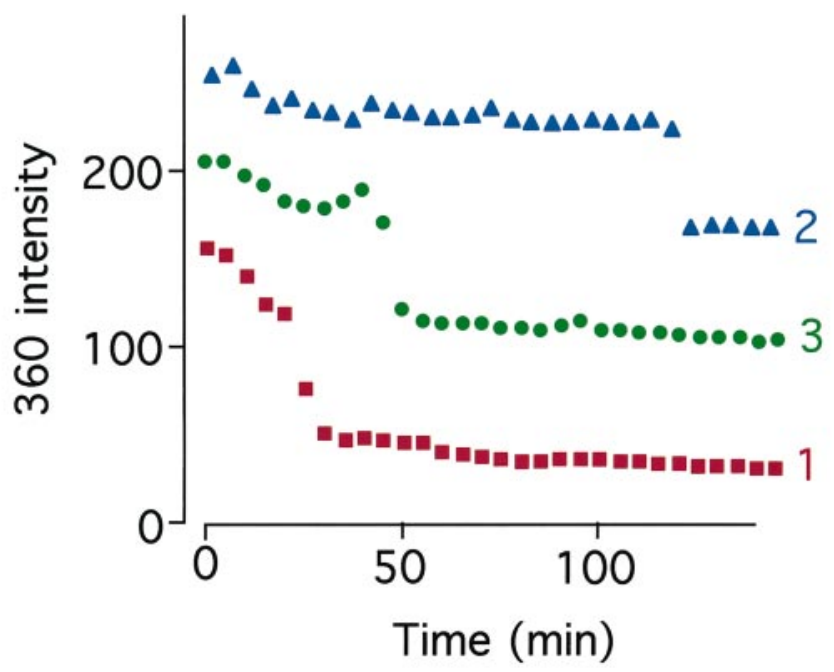

$\left[\mathrm{Ca}^{2+}\right]_{\mathrm{i}}$ during ischemia also was observed sometimes (Fig. 5D). The existence of both early and late components to the $\left[\mathrm{Ca}^{2+}\right]_{i}$ response during ischemia correlated with the incidence of ischemic cell death (see Fig. $3 A$ ).

\section{Ionotropic glutamate receptors}

Both early and late ischemic $\left[\mathrm{Ca}^{2+}\right]_{\mathrm{i}}$ responses were observed in the presence of the broad-spectrum ionotropic glutamate receptor antagonist kynurenic acid (1 mM) (Fig. 6A). In all, $60 \pm 4.1 \%$ of the cells died in the presence of kynurenic acid during ischemia experiments, which was not significantly different from the incidence of cell death in the absence of the antagonist (102 of 170 cells, 3 nerves; $p>0.5$ ) (see Fig. 12). The pattern of cell death was also similar to that found with no kynurenic acid present, with an end of the period of ischemia (Fig. $5 B$ ). Occasionally, both patterns were apparent in a single cell (Fig. $5 C$ ). A plateau in ward baseline (Fig. $5 A$ ). Note from the 360 intensity plot that this cell did not die at the point of maximal $\left[\mathrm{Ca}^{2+}\right]_{\mathrm{i}}$. Small changes in the 360 signal during ischemia may reflect changes in cell volume, with accompanying changes in the concentration of fura-2. Other cells showed a slow increase in $\left[\mathrm{Ca}^{2+}\right]_{\mathrm{i}}$ that peaked toward the 

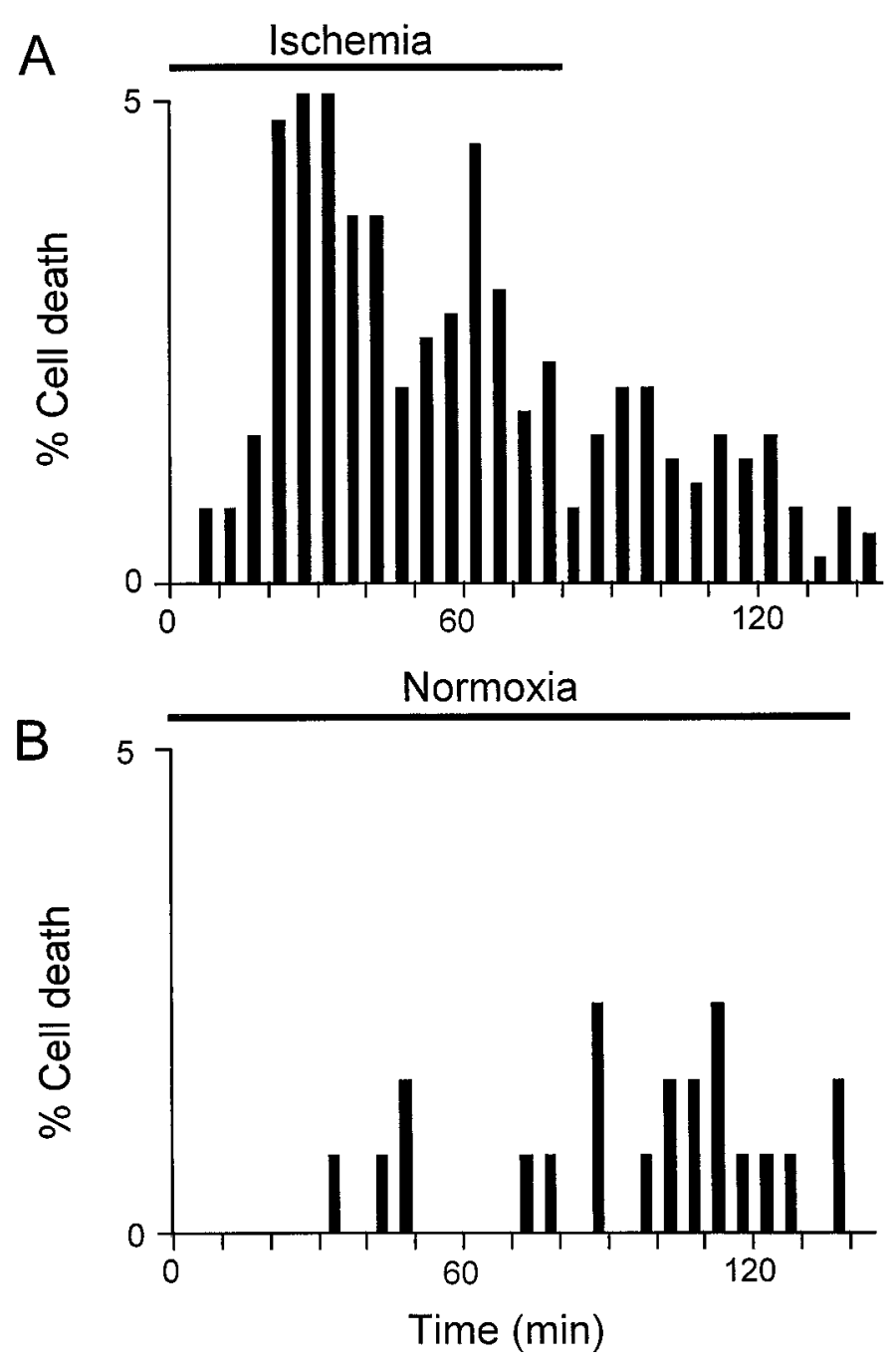

Figure 3. The incidence of cell death during ischemia and under control conditions. $A$, The percentage of the total initial number of cells that die in each $5 \mathrm{~min}$ epoch is plotted against time for ischemia experiments. Note that cell death rises to a peak between 20 and $35 \mathrm{~min}$ of ischemia, with a second peak between 55 and $70 \mathrm{~min}$. $B$, Similar plot for control experiments in which nerves are perfused with oxygenated aCSF throughout.

early peak and continued cell death during the second half of the ischemic period (see Fig. 7B).

\section{Voltage-gated $\mathrm{Ca}^{2+}$ channels}

No late increases in $\left[\mathrm{Ca}^{2+}\right]_{\mathrm{i}}$ were observed during ischemia in the presence of the L-type voltage-gated $\mathrm{Ca}^{2+}$ channel blocker diltiazem $(50 \mu \mathrm{M})$ (Fig. 6B). A distinct early component was common in the presence of diltiazem, which was also apparent in nerves perfused with combined $1 \mathrm{~mm}$ kynurenic acid and $50 \mu \mathrm{M}$ diltiazem (Fig. 6C). The incidence of cell death was reduced to $42.8 \pm 6.8 \%$ in the presence of $50 \mu \mathrm{M}$ diltiazem, significantly less than in the absence of the antagonist ( 89 of 208 cells, 4 nerves; $p<0.001$ ) (see Fig. 12). The pattern of cell death reflected this change in $\left[\mathrm{Ca}^{2+}\right]_{\mathrm{i}}$ influx during ischemia, with a distinct early phase of ischemic cell death evident (Fig. 7A). Similar results were obtained with nifedipine ( $5 \mu \mathrm{m} ; 2$ nerves) (data not shown).

Nerves perfused with the T-type voltage-gated $\mathrm{Ca}^{2+}$ channel blocker $\mathrm{Ni}^{2+}(400 \mu \mathrm{M})$ showed small or nonexistent early increases in $\left[\mathrm{Ca}^{2+}\right]_{\mathrm{i}}$ during ischemia and distinct late increases (Fig. 8A). The incidence of cell death reflected this pattern of $\mathrm{Ca}^{2+}$ influx, with no early phase of cell death in the presence of $400 \mu \mathrm{M} \mathrm{Ni}^{2+}$ (Fig. $8 B$ ). The incidence of cell death in the presence of $\mathrm{Ni}^{2+}$ was $35 \pm 3.3 \%$, significantly lower than in the absence of $\mathrm{Ni}^{2+}$ (62 of 177 cells, 3 nerves; $p<0.001$ ) (see Fig. 12).

Little change in $\left[\mathrm{Ca}^{2+}\right]_{\mathrm{i}}$ was observed during ischemia in cells perfused with combined $400 \mu \mathrm{M} \mathrm{Ni}^{2+}$ and $50 \mu \mathrm{M}$ diltiazem (Fig. $9 A)$. Occasional $\left[\mathrm{Ca}^{2+}\right]_{\mathrm{i}}$ changes occurred in the postischemic period and were associated with some cell death (Fig. 9B,C). The overall incidence of cell death was $26.9 \pm 9.0 \%$, which was somewhat higher than the incidence of cell death in the absence of ischemia (77 of 286 cells, 5 nerves; $p<0.01$ ) (see Fig. 12), but was not significantly different from that found in ischemia experiments performed in the absence of extracellular $\mathrm{Ca}^{2+}(p>0.1)$ (see Fig. 12).

\section{$\mathrm{Na}^{+}-\mathrm{Ca}^{2+}$ exchange}

The $\mathrm{Na}^{+}-\mathrm{Ca}^{2+}$ exchanger plays an important role in anoxic injury in the mature RON, where changes in intracellular $\mathrm{Na}^{+}$, $\mathrm{Ca}^{2+}$, and membrane potential establish the conditions that are necessary for significant $\mathrm{Ca}^{2+}$ influx via this protein (Stys et al., 1992). $\mathrm{Na}^{+}-\mathrm{Ca}^{2+}$ exchange was blocked with the inhibitor bepridil $(50 \mu \mathrm{M})$. Perfusion with bepridil in the absence of ischemia had no effect on baseline $\left[\mathrm{Ca}^{2+}\right]_{\mathrm{i}}$ (data not shown) nor on the incidence of cell death when compared with perfusion with aCSF ( $14 \%$ of the cells died; 9 of 65 cells, 1 nerve). The onset of ischemia in the presence of bepridil resulted in large increases in $\left[\mathrm{Ca}^{2+}\right]_{\mathrm{i}}($ Fig. $10 A) \cdot\left[\mathrm{Ca}^{2+}\right]_{\mathrm{i}}$ continued to rise in all cells and fell only slightly or not at all during the recovery period (Fig. 10A). The incidence of cell death in ischemia experiments performed in the presence of bepridil was $62.5 \pm 12.7 \%$, which was not significantly different from in the absence of bepridil (100 of 160 cells, 3 nerves; $p>0.5$ ) (see Fig. 12). The pattern of ischemic cell death in the presence of $50 \mu \mathrm{M}$ bepridil is shown in Figure $10 \mathrm{~B}$.

\section{Nonselective inorganic $\mathrm{Ca}^{2+}$ channel blockers}

$\mathrm{Ca}^{2+}$ flux across the cell membrane can be inhibited in a nonselective manner by metal ions such as $\mathrm{La}^{3+}, \mathrm{Cd}^{2+}$, and high concentrations of $\mathrm{Ni}^{2+}$ (Hille, 1992). A complication of these metals is that they interact with dyes such as fura-2, resulting in false positive responses if the metal penetrates into the cell (Haugland, 1996). Perfusion with $100 \mu \mathrm{M} \mathrm{La}{ }^{3+}$ blocked all changes in $\left[\mathrm{Ca}^{2+}\right]_{\mathrm{i}}$ during ischemia in the majority of cells studied (Fig. 11 $A$, open squares), but a significant increase in the 340:380 ratio was observed occasionally in some cells in the recovery period (Fig. $11 \mathrm{~A}$, filled circles). This late signal was not associated with cell death (Fig. $11 B$ ). The incidence of cell death was similar to that found in ischemia experiments performed in the absence of $\mathrm{Ca}^{2+}(25.5 \pm 5.7 \%$; 50 cells of 196,3 nerves; $p<$ 0.001) (Fig. 12). Similar results were obtained with $2 \mathrm{~mm} \mathrm{Ni}^{2+}$ (data not shown). Perfusion with $100 \mu \mathrm{M} \mathrm{Cd}^{2+}$ resulted in a rapid increase in the 340:380 ratio, which was not associated with cell death (data not shown).

The incidence of cell death during the $145 \mathrm{~min}$ time course of experiments under different conditions is summarized in Figure 12. A significant reduction in cell death was produced by perfusion with blockers of voltage-gated $\mathrm{Ca}^{2+}$ channels or by the removal of extracellular $\mathrm{Ca}^{2+}$, but not by the block of ionotropic glutamate receptors or $\mathrm{Na}^{+}-\mathrm{Ca}^{2+}$ exchange. 
Figure 4. Ischemic changes in $\left[\mathrm{Ca}^{2+}\right]_{\mathrm{i}}$ are dependent on extracellular $\mathrm{Ca}^{2+} . A$, The 340 : 380 ratio (filled circles, left scale) and 360 intensity (open squares, right scale) recorded from a representative cell during an ischemia experiment performed in the absence of extracellular $\mathrm{Ca}^{2+}$. There was no change in 340:380 ratio, and cell death did not occur. $B$, A similar plot for a cell that died during ischemia in the absence of extracellular $\mathrm{Ca}^{2+}$. Note that no increase in the 340:380 ratio occurred before cell death. $C$, A cell that died under control conditions, in oxygenated aCSF. Note that the 340:380 ratio increases before cell death. $D$, The incidence of cell death in ischemia experiments performed in the absence of extracellular $\mathrm{Ca}^{2+}$ (open bars). Ischemic cell death in normal $\mathrm{Ca}^{2+}$ is shown for comparison (filled bars). The shaded box on the time axis represents the period of ischemia.
A

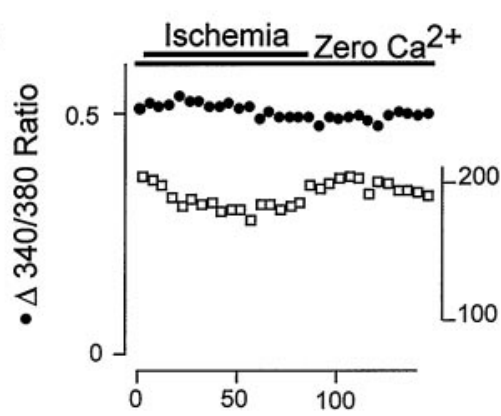

B

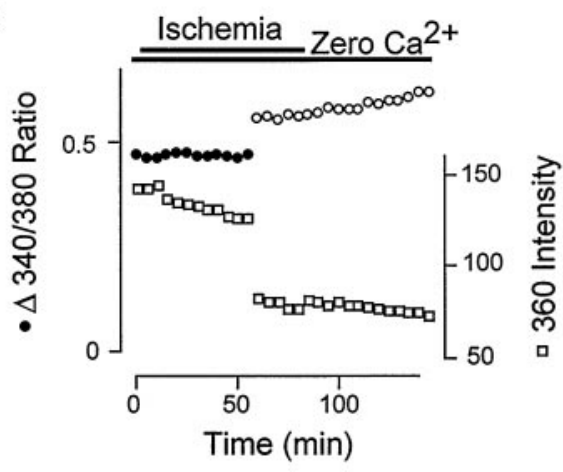

A

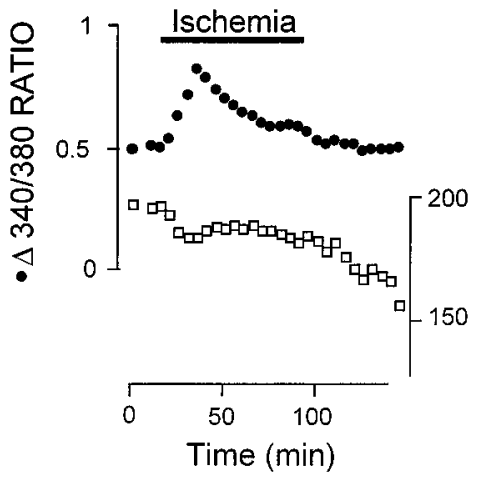

Figure 5. Changes in $\left[\mathrm{Ca}^{2+}\right]_{\mathrm{i}}$ during ischemia. The 340:380 ratio (filled circles, left scale) and 360 intensity (open squares, right scale) were recorded from four cells during ischemia experiments. $A,\left[\mathrm{Ca}^{2+}\right]_{\mathrm{i}}$ rises quickly during ischemia, reaches a peak, and declines almost to resting during the ongoing insult. $B,\left[\mathrm{Ca}^{2+}\right]_{\mathrm{i}}$ rises slowly during ischemia and starts to decline only in the recovery period. $C$, Both an initial and a late increase in $\left[\mathrm{Ca}^{2+}\right]_{\mathrm{i}} . D,\left[\mathrm{Ca}^{2+}\right]_{\mathrm{i}}$ rises quickly, reaches a plateau, and starts to recover only once the control conditions are reestablished. Note that none of these cells died.
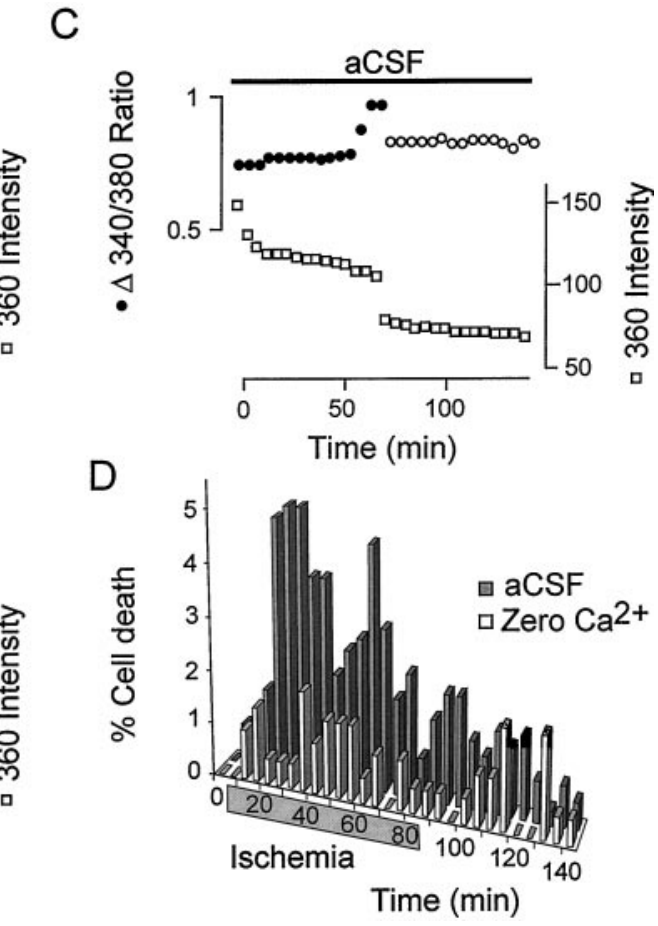

B

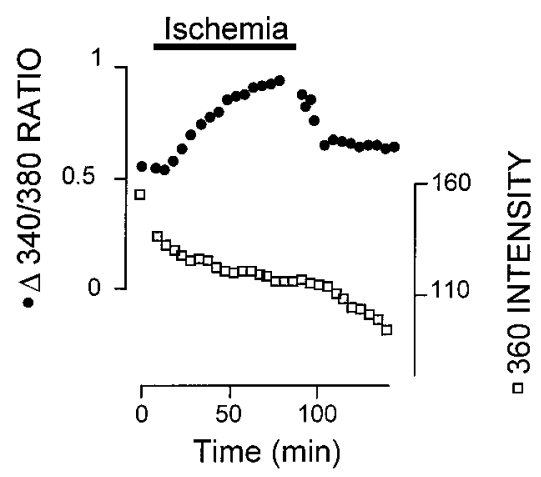

D

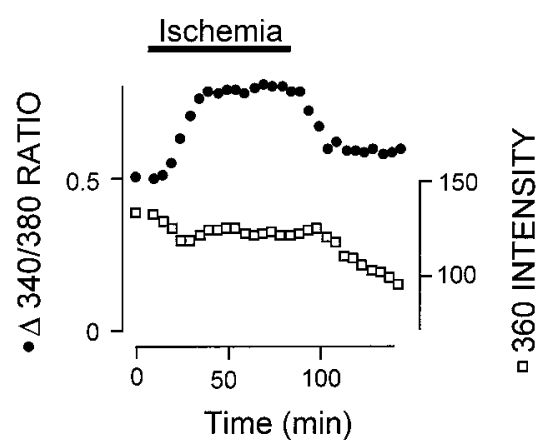

\section{Delayed cell death}

Cell death that occurred in the 60 min recovery period after the $80 \mathrm{~min}$ of ischemia was associated with two patterns of $\left[\mathrm{Ca}^{2+}\right]_{\mathrm{i}}$ change. Either cells showed an increase in $\left[\mathrm{Ca}^{2+}\right]_{\mathrm{i}}$ during ischemia that fell back to baseline and was followed by a second increase in $\left[\mathrm{Ca}^{2+}\right]_{\mathrm{i}}$ that was associated with cell death (Fig. 13A), or the cells maintained an increase in $\left[\mathrm{Ca}^{2+}\right]_{\mathrm{i}}$ that eventually was associated with cell death (Fig. 13B). Delayed cell death, defined as the percentage of the cells that were alive after the $80 \mathrm{~min}$ period of ischemia (or $80 \mathrm{~min}$ of perfusion with normal aCSF for control cells) but that subsequently died, is shown for a number of conditions in Figure $13 C$. Delayed cell death was significantly more common after $80 \mathrm{~min}$ of ischemia than after $80 \mathrm{~min}$ of perf usion with aCSF $(27.9 \pm 7.0 \%$ as compared with $3.5 \pm 2.4 \%$, respectively; $p<0.05$ ). Delayed cell death after ischemia was reduced to control levels when $\mathrm{Ca}^{2+}$ was absent from the aCSF $(1.1 \pm 0.3 \% ; p<0.001$ as compared with ischemia in normal $\mathrm{aCSF}$ ) and was not significantly different from that found after 
A

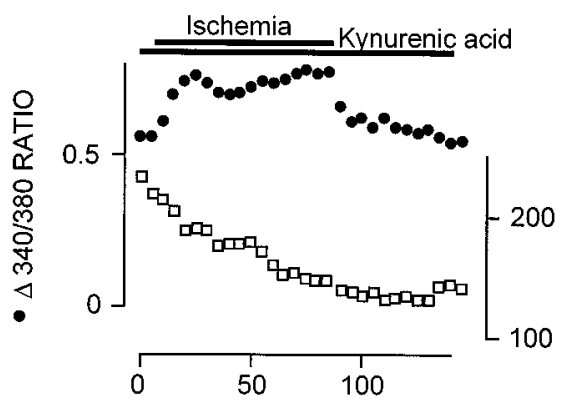

B

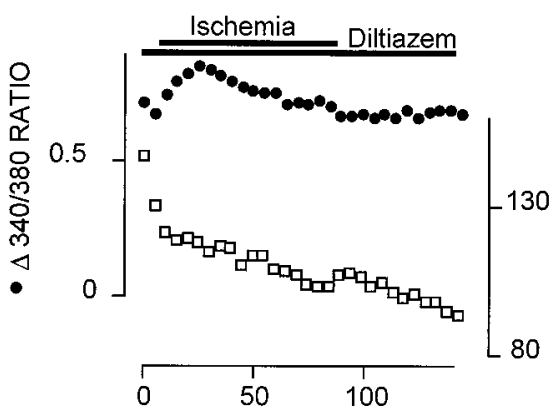

C

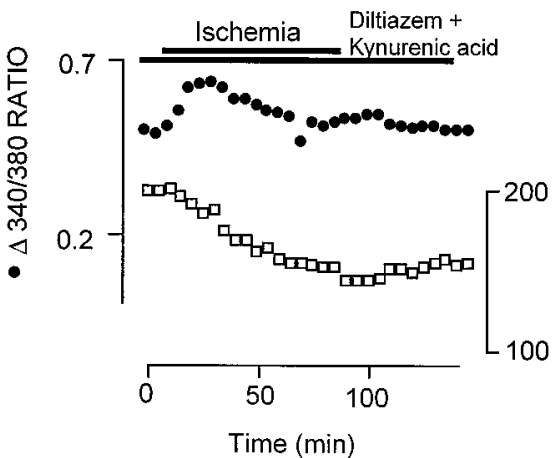

A

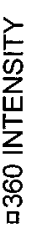

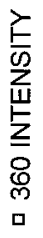

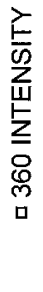

Figure 6. The late increase in $\left[\mathrm{Ca}^{2+}\right]_{\mathrm{i}}$ is attributable to $\mathrm{Ca}^{2+}$ influx through L-type channels. $A$, The $340: 380$ ratio and 360 intensity of a cell during an ischemia experiment performed in the presence of the nonselective ionotropic glutamate antagonist kynurenic acid $(1 \mathrm{mM})$. Both an early and a late $\mathrm{Ca}^{2+}$ influx are apparent. $B$, A similar plot from an ischemia experiment performed in the presence of the L-type $\mathrm{Ca}^{2+}$ channel blocker diltiazem $(50 \mu \mathrm{M})$. Note that only an early change in $\left[\mathrm{Ca}^{2+}\right]_{\mathrm{i}}$ is present. $C$, A plot from an ischemia experiment performed in the combined presence of $1 \mathrm{~mm}$ kynurenic acid and $50 \mu \mathrm{M}$ diltiazem. None of these representative cells dies.

ischemia in the presence of $400 \mu \mathrm{M} \mathrm{Ni}{ }^{2+}$ and $50 \mu \mathrm{M}$ diltiazem combined $(22.2 \pm 8.6 \% ; p>0.05)$ or $100 \mu \mathrm{M} \mathrm{La}{ }^{3+}(11.9 \pm 2.5 \%$; $p>0.05)$.

\section{DISCUSSION}

In situ $\mathrm{nRON}$ astrocytes were highly sensitive to ischemia. Rises in $\left[\mathrm{Ca}^{2+}\right]_{\mathrm{i}}$ occurred within $5-10 \mathrm{~min}$ of ischemia, and significant cell death was apparent after 10-20 min. The high ischemic sensitivity resulted from $\mathrm{Ca}^{2+}$ influx through T-type channels. This is the first time such a phenomenon has been reported. No ischemic $\left[\mathrm{Ca}^{2+}\right]_{\mathrm{i}}$ rises occurred in $\mathrm{Ca}^{2+}$-free solution, indicating that there was no significant $\mathrm{Ca}^{2+}$ release from intracellular stores. It is possible that transient noninflux-mediated changes in $\left[\mathrm{Ca}^{2+}\right]_{\mathrm{i}}$ occurred that were not recorded with the image collection rate that was used. However, the near-complete protection
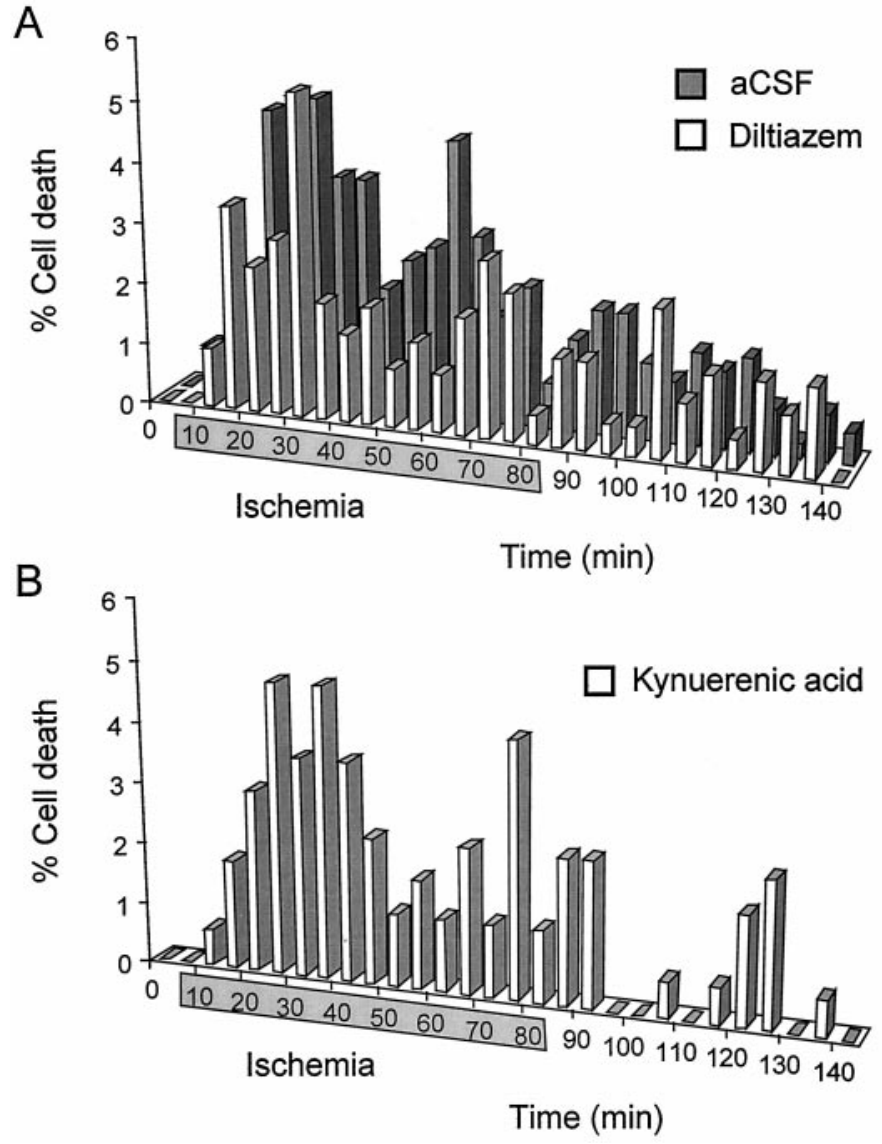

Figure 7. $A$, The incidence of cell death in the presence of $50 \mu \mathrm{M}$ diltiazem (open bars). Cell death in normal $\mathrm{Ca}^{2+}$ is shown for comparison ( filled bars). The shaded box on the time axis represents the period of ischemia. Note that an early peak in the incidence of cell death is present in diltiazem. $B$, The incidence of cell death in the presence of $1 \mathrm{~mm}$ kynurenic acid.

from injury produced by the block of $\mathrm{Ca}^{2+}$ influx demonstrated that any such intracellular $\mathrm{Ca}^{2+}$ release was not important for cell viability. Significant prolonged ischemic $\mathrm{Ca}^{2+}$ release from intracellular stores occurs in gray matter astrocytes in situ (Duffy and MacVicar, 1996) and is apparently a ubiquitous feature of ischemia in neurons (Duchen et al., 1990; Dubinsky and Rothman, 1991; Friedman and Haddad, 1993; Hasham et al., 1994).

Cells responded to ischemia with either an early $\left[\mathrm{Ca}^{2+}\right]_{i}$ influx, a late $\left[\mathrm{Ca}^{2+}\right]_{\mathrm{i}}$ influx, or a combination of the two. Both the early and late components of $\mathrm{Ca}^{2+}$ influx were associated with cell death. Early $\mathrm{Ca}^{2+}$ influx/cell death was blocked selectively by $\mathrm{Ni}^{2+}$, and late $\mathrm{Ca}^{2+}$ influx/cell death was prevented by L-type $\mathrm{Ca}^{2+}$ channel blockers. Both were blocked by $\mathrm{La}^{3+}$ and were unaffected by kynurenic acid. The results are summarized in Figure 14.

\section{Colocalization of fura-2 and GFAP}

Previous studies have colocalized fura-2-loaded cells indirectly with immunological markers (Porter and McCarthy, 1995). The current technique was adapted from that used to fix other BAPTA-type dyes by Tymianski et al. (1997). This allowed for the identification of fura-2-loaded cells in the optic nerve as a population of $\mathrm{GFAP}^{+}$astrocytes located around the periphery of the nerve. Astrocytes present in the RON at birth constitute three morphological groups: (1) "undifferentiated" cells, (2) "trans- 
A
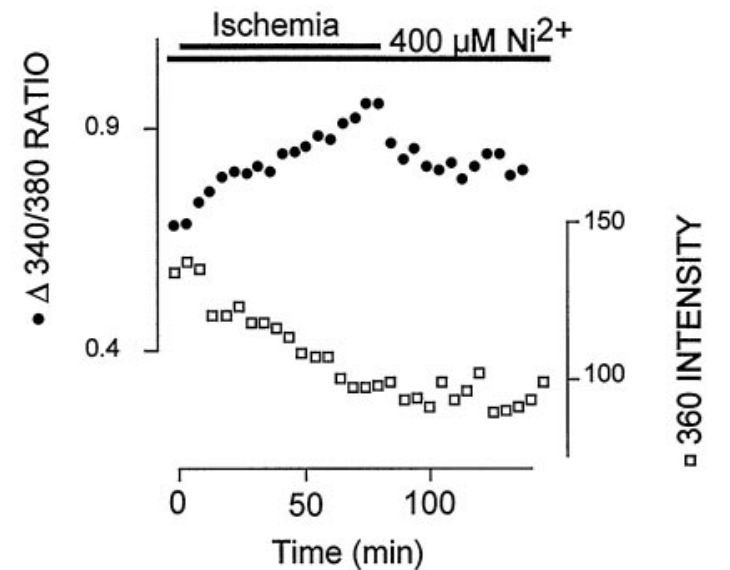

B

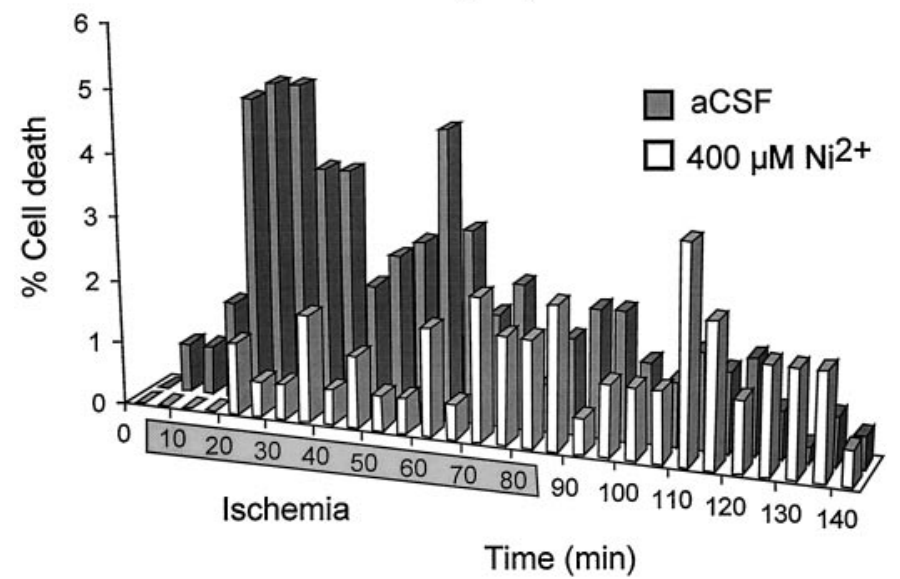

Figure 8. Early $\mathrm{Ca}^{2+}$ influx and early cell death are blocked by $\mathrm{Ni}^{2+} \cdot A$, The 340:380 ratio and 360 intensity of a representative cell from an ischemia experiment performed in the presence of $400 \mu \mathrm{M} \mathrm{Ni}^{2+}$. Note that there is a gradual increase in $\left[\mathrm{Ca}^{2+}\right]_{i}$, with no early component. The cell does not die. $B$, The incidence of cell death in the presence of $400 \mu \mathrm{M}$ $\mathrm{Ni}^{2+}$ (open bars). Note that there is no early peak in the incidence of cell death. Cell death in normal $\mathrm{Ca}^{2+}$ is shown for comparison (filled bars). The shaded box on the time axis represents the period of ischemia.

verse" cells that resemble radial glia, and (3) "randomly oriented" cells found in the subpial region (Butt and Ransom, 1993). Preferential dye loading of subpial cells in the current study is presumably a consequence of the incubation method that was used. In a previous imaging study of nRON glia, fluo-3 AM was injected into the center of the nerve (Kriegler and Chiu, 1993). The particular cell type that loaded fluo-3 was not identified. In the current study only a small amount of fura- 2 was found within the nerve core. It was unclear if this represented dye in out-of-focus astrocytes or whether dye had loaded to some extent into axons or astrocyte processes. Intense GFAP staining occurred in these deeper parts of the nerve, as previously reported (Ochi et al., 1993).

\section{Ischemic $\mathrm{Ca}^{2+}$ influx}

Astrocytes in culture can express both L- and T-type $\mathrm{Ca}^{2+}$ channels, depending on the culture conditions (Barres et al., 1989, 1990; Corvalan et al., 1990; Verkhratsky et al., 1998). $\mathrm{Ca}^{2+}$ channels at least partly mediate anoxic injury in cultured astrocytes (Yu et al., 1989; Haun et al., 1992). At P2, nRON astrocytes removed via "tissue print" exhibit both T-type and L-type channels, with T-type channels in greater density than L-type (Barres et al., 1990). The late ischemic $\mathrm{Ca}^{2+}$ influx and cell death in the

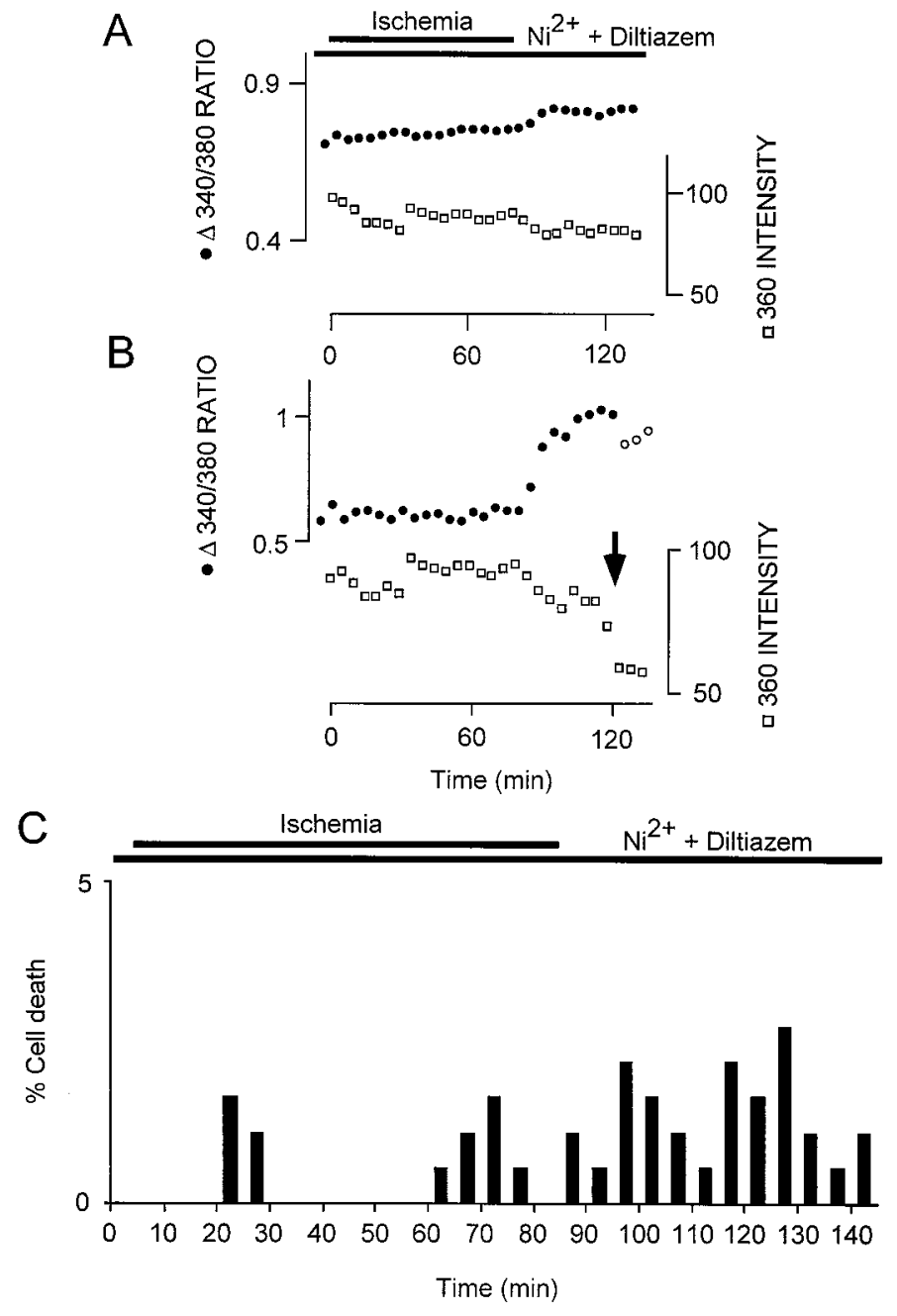

Figure 9. Combined T-type and L-type $\mathrm{Ca}^{2+}$ channel block removes both early and late $\mathrm{Ca}^{2+}$ influx during ischemia and mitigates early and late cell death. $A$, The $340: 380$ ratio and 360 intensity of a representative cell from an ischemia experiment performed in the presence of $400 \mu \mathrm{M}$ $\mathrm{Ni}^{2+}$ and $50 \mu \mathrm{M}$ diltiazem. No significant change in $\left[\mathrm{Ca}^{2+}\right]_{\mathrm{i}}$ occurs, and the cell does not die. $B$, Similar plot showing a cell that dies under the same experimental conditions. Note that cell death (indicated by the arrow) is preceded by an increase in $\left[\mathrm{Ca}^{2+}\right]_{\mathrm{i}} . C$, The incidence of cell death in an ischemia experiment in the presence of $400 \mu \mathrm{M} \mathrm{Ni}^{2+}$ and 50 $\mu \mathrm{M}$ diltiazem. Note that little cell death occurs during ischemia.

current experiments were mediated by pharmacologically identified L-type channels. The early $\mathrm{Ca}^{2+}$ influx was not blocked by L-type channel blockers, but it was blocked by $\mathrm{Ni}^{2+}$ concentrations too low to affect L-type channels in the same cells. Greater sensitivity to $\mathrm{Ni}^{2+}$ than is exhibited by L-type channels is a characteristic of T-type channels (Hille, 1992). The documented presence of $\mathrm{T}$-type $\mathrm{Ca}^{2+}$ channels in nRON astrocytes, the absence of other $\mathrm{Ca}^{2+}$ channels in these cells apart from L-type (Barres et al., 1990), the resistance of early $\mathrm{Ca}^{2+}$ influx to L-type channel blockers and its sensitivity to $\mathrm{Ni}^{2+}$-all indicate that the early component of $\mathrm{Ca}^{2+}$ influx during ischemia is T-type channel-mediated.

Astrocytes in situ respond to ischemia with a gradual membrane depolarization from a resting potential of approximately $-80 \mathrm{mV}$ (Duffy and MacVicar, 1996). Depolarization from -80 $\mathrm{mV}$ will activate $\mathrm{T}$-type channels, although they inactivate rapidly after step voltage changes (Hille, 1992). T-type channels inacti- 

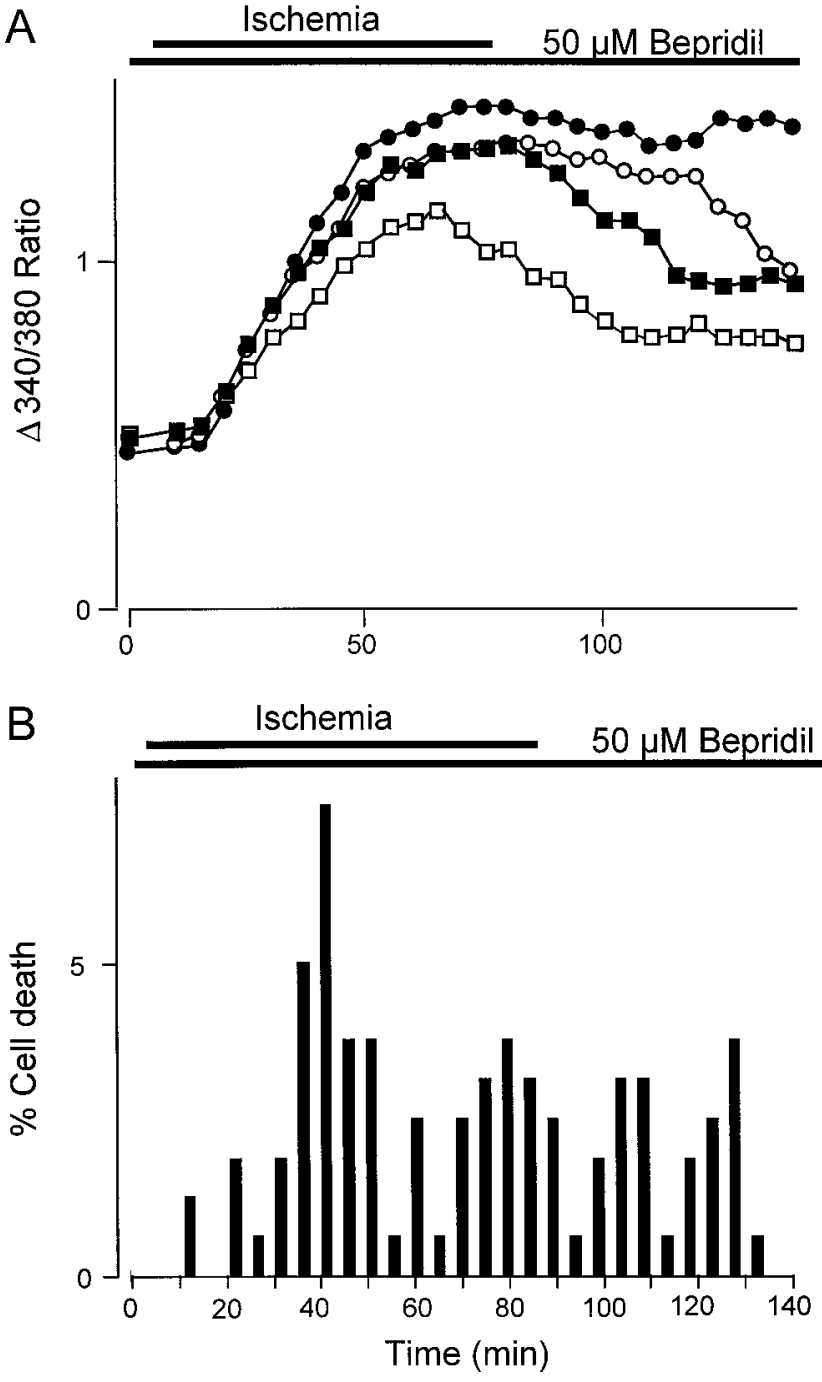

Figure 10. Perfusion with bepridil during ischemia. A, The 340:380 ratios of four representative cells from an ischemia experiment performed in the presence of the $\mathrm{Na}^{+}-\mathrm{Ca}^{2+}$ exchange inhibitor bepridil $(50 \mu \mathrm{M})$. $\left[\mathrm{Ca}^{2+}\right]_{\mathrm{i}}$ increases in all cells, and no fall in $\left[\mathrm{Ca}^{2+}\right]_{\mathrm{i}}$ is found during ischemia. Partial recovery of $\left[\mathrm{Ca}^{2+}\right]_{i}$ is apparent in some cells after ischemia. $B$, The incidence of cell death during ischemia experiments performed in the presence of $50 \mu \mathrm{M}$ bepridil.

vate more slowly after smaller voltage changes (Fox et al., 1987; Ryu and Randic, 1990), and it may be that this voltage dependence of inactivation results in prolonged currents during gradual ischemic depolarization. Alternatively, a brief $\mathrm{T}$-type $\mathrm{Ca}^{2+}$ current during the initial ischemic depolarization may elevate $\left[\mathrm{Ca}^{2+}\right]_{\mathrm{i}}$ for several tens of minutes before the $\mathrm{Ca}^{2+}$ is removed from the cytoplasm.

\section{$\mathrm{Ca}^{2+}$ extrusion}

The initial phase of $\mathrm{Ca}^{2+}$ influx during ischemia was often transitory, with $\left[\mathrm{Ca}^{2+}\right]_{\mathrm{i}}$ declining toward baseline during the ongoing insult. Two membrane proteins are responsible for $\left[\mathrm{Ca}^{2+}\right]_{\mathrm{i}}$ homeostasis: the $\mathrm{Na}^{+}-\mathrm{Ca}^{2+}$ exchanger and $\mathrm{Ca}^{2+}{ }_{-}$ ATPase. Bepridil, a blocker of $\mathrm{Na}^{+}-\mathrm{Ca}^{2+}$ exchange, removed the ability of cells to regulate $\left[\mathrm{Ca}^{2+}\right]_{\mathrm{i}}$ during ischemia. The exchanger is therefore at least partly responsible for ischemic $\left[\mathrm{Ca}^{2+}\right]_{\mathrm{i}}$ regulation in these cells. However, the inhibition of $\mathrm{Ca}^{2+}-$ ATPase by bepridil cannot be ruled out (Kaczorowski et
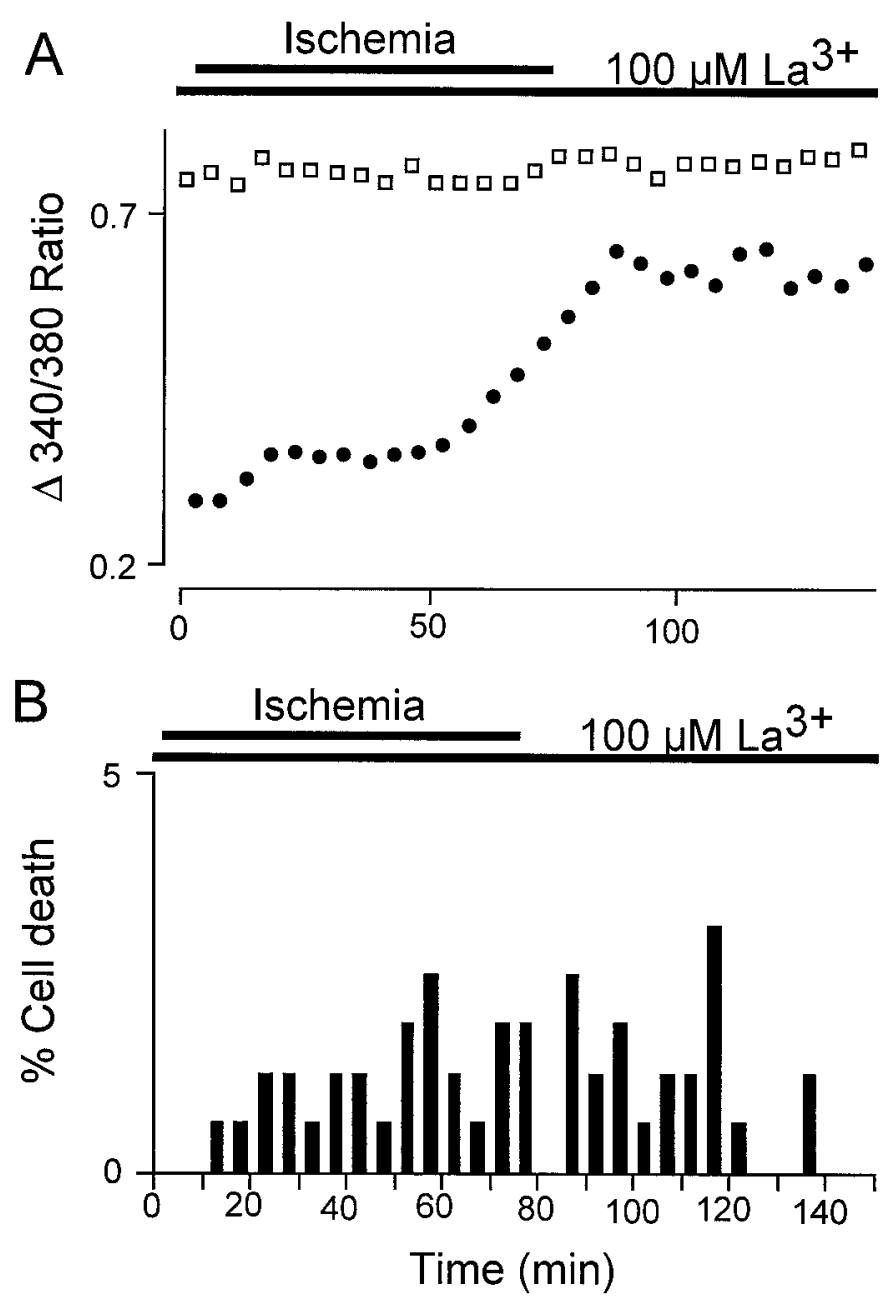

Figure 11. Perfusion with $\mathrm{La}^{3+}$ during ischemia. $A$, The $340: 380$ ratios of two cells from an ischemia experiment performed in the presence of $100 \mu \mathrm{M} \mathrm{La}^{3+}$. The top recording (open squares) is from a representative cell that shows no significant change in 340:380 ratio during or after ischemia. The bottom recording ( filled circles) shows a large increase in ratio in the latter part of the experiment. This kind of response was found in a significant minority of cells. Neither cell died (data not shown). $B$, The incidence of cell death in ischemia experiments performed in the presence of $100 \mu \mathrm{M} \mathrm{La}^{3+}$. A low level of cell death is present throughout.

al., 1989), precluding any firm conclusion regarding an exclusive role for the exchanger. Large and long-lasting increases in $\left[\mathrm{Ca}^{2+}\right]_{\mathrm{i}}$ were found consistently during ischemia in the presence of bepridil (see Fig. 10A). However, the amount of cell death was not significantly greater than in the absence of the drug. This paradox may indicate a ceiling level of $\left[\mathrm{Ca}^{2+}\right]_{\mathrm{i}}$ beyond which any further increase is not translated into a greater probability of cell death.

High $\left[\mathrm{Na}^{+}\right]_{\mathrm{i}}$ and membrane depolarization favor the $\mathrm{Ca}^{2+}$ import mode of the $\mathrm{Na}^{+}-\mathrm{Ca}^{2+}$ exchanger (Goldman et al., 1994; Stys et al., 1992). Cultured spinal cord astrocytes respond to chemical ischemia with large and rapid increases in $\left[\mathrm{Na}^{+}\right]_{\mathrm{i}}$ (Rose et al., 1998). If similar changes in $\left[\mathrm{Na}^{+}\right]_{\mathrm{i}}$ occur in nRON astrocytes, the exchanger would import rather than export $\mathrm{Ca}^{2+}$. Astrocytes removed from $\mathrm{P} 2 \mathrm{nRON}$ by tissue print exhibit no detectable $\mathrm{Na}^{+}$conductance (Barres et al., 1990). This contrasts with astrocytes cultured in the presence of certain chemical factors (Barres et al., 1989), mature RON astrocytes (Barres et 


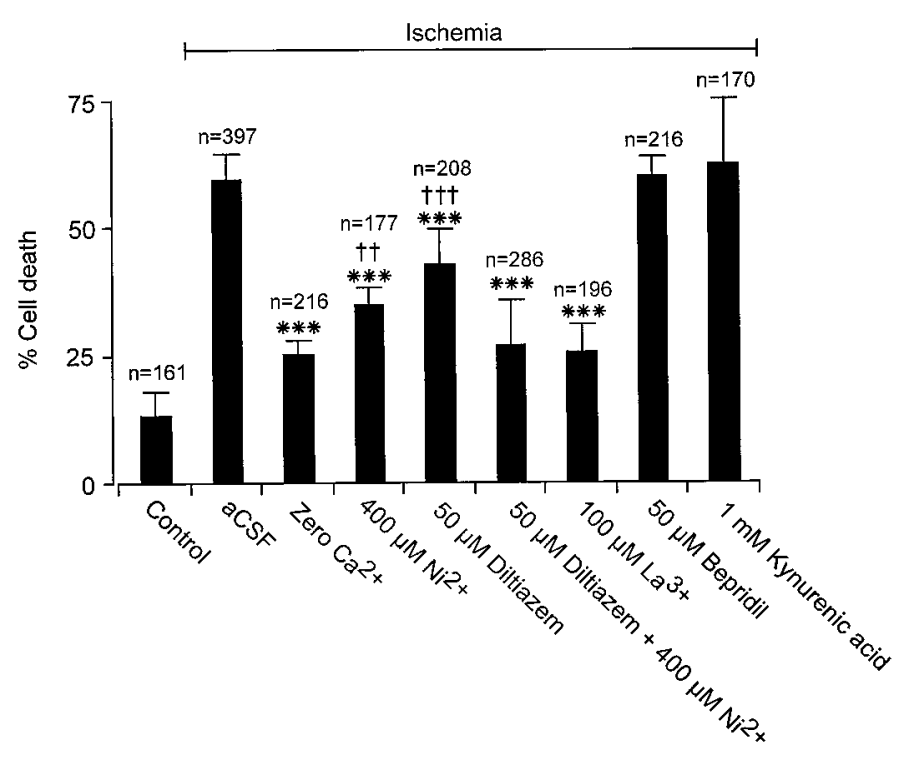

Figure 12. Histogram showing the incidence of cell death in ischemia experiments performed in various solutions. $n$ represents sample size (cells); *** represents statistical significance as compared with cell death in normal aCSF $(p<0.001)$; ${ }^{\dagger+}$ represents statistical significance as compared with cell death in ischemia experiments performed in zero $\mathrm{Ca}^{2+}\left(p<0.05 ;{ }^{\dagger \dagger}<0.01\right)$.

al., 1990), and mature RON axons (Stys et al., 1993). $\mathrm{Na}^{+}$ currents have been recorded from a small proportion of neonatal gray matter astrocytes in vitro (Sontheimer and Waxman, 1993). The low $\mathrm{Na}^{+}$conductance of nRON astrocytes may limit $\mathrm{Na}^{+}$ influx during ischemia, permitting the export of $\mathrm{Ca}^{2+}$ via the exchanger. This may be a unique feature of neonatal white matter astrocytes, because in all other CNS cells that have been studied the $\mathrm{Na}^{+}-\mathrm{Ca}^{2+}$ exchanger does not remove cytoplasmic $\mathrm{Ca}^{2+}$ effectively during ischemia, and in many cells the exchanger is a significant source of ischemic $\mathrm{Ca}^{2+}$ influx (Stys et al., 1992; Lobner and Lipton, 1993).

\section{Cell death}

A correlation was found between cell death and high $\left[\mathrm{Ca}^{2+}\right]_{\mathrm{i}}$. During ischemia and in the postischemic period cell death was always preceded by increased $\left[\mathrm{Ca}^{2+}\right]_{\mathrm{i}}$, as was cell death under control conditions. Manipulations that reduced ischemic $\left[\mathrm{Ca}^{2+}\right]_{\mathrm{i}}$ rises also reduced the extent of cell death. These results are consistent with the $\mathrm{Ca}^{2+}$ hypothesis that states that high $\left[\mathrm{Ca}^{2+}\right]_{\mathrm{i}}$ is a common pathway for cell death (Choi, 1988; Siesjo and Bengtsson, 1989). However, during perfusion with zero $\mathrm{Ca}^{2+}$ solution a significantly greater level of ischemic cell death occurred than in normal aCSF (no ischemia). In zero $\mathrm{Ca}^{2+}$, ischemic cell death was not preceded by high $\left[\mathrm{Ca}^{2+}\right]_{i}$ within the time resolution of recordings. It may be that in the absence of extracellular $\mathrm{Ca}^{2+}$ a degree of cell death occurred that was not $\mathrm{Ca}^{2+}$-mediated, as has been reported in neonatal neurons (Friedman and Haddad, 1993).

\section{Relevance to periventricular leukomalacia}

All evidence indicates that glial cell death occurs in the early stages of periventricular leukomalacia (see introductory remarks). There may be a causal relationship between glial injury and the subsequent development of the lesion, because both astrocytes and oligodendrocytes are involved in the normal maturation of white matter. Previous studies have focused on oligo-
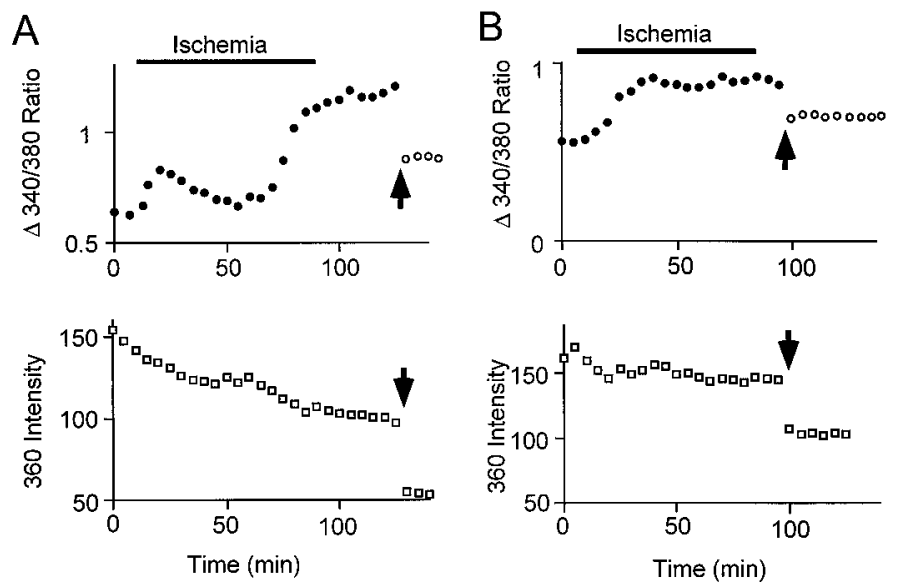

C

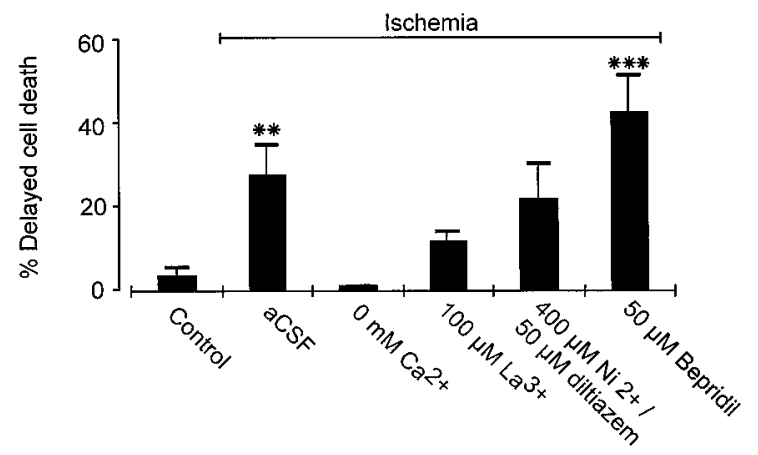

Figure 13. Two patterns of delayed cell death after ischemia. $A, B$, Plots of 340:380 ratio (top) and 360 intensity (bottom) from ischemia experiments. $A$, Ischemia is associated with an early $\mathrm{Ca}^{2+}$ influx that is not associated with cell death and a late influx that is (cell death indicated by arrows). $B$, Ischemia is associated with $\mathrm{Ca}^{2+}$ influx that does not return to baseline and is associated with cell death. $C$, Delayed cell death, defined as the percentage of cells alive at the end of ischemia that subsequently die in the recovery period, under various conditions. Delayed cell death is abolished by removing $\mathrm{Ca}^{2+}$ from the perfusing solution and is reduced to nonsignificant levels by a block of $\mathrm{Ca}^{2+}$ influx. ** represents statistical significance as compared with delayed cell death in control conditions $(p<0.05 ; * * * p 0.01)$.

dendrocyte injury because of the role these cells play in myelination (Volpe, 1995). The current study has concentrated on neonatal white matter astrocytes. The results demonstrate unexpected novelty in the mechanisms of ischemic injury of these cells, in particular the role of T-type $\mathrm{Ca}^{2+}$ channels. Barres et al. (1990) have shown that T-type channels are expressed between P0 and P10 in optic nerve astrocytes, a period in development when this tissue closely resembles the neonatal human white matter regions that are subject to periventricular leukomalacia (DeReuck et al., 1972; Romijn et al., 1991). In addition to a potential direct contribution to the development of periventricular leukomalacia, astrocyte death during ischemia also may be a contributing factor in oligodendrocyte injury. For example, $\mathrm{Ca}^{2+}$-mediated astrocyte death results in the release of a toxic factor, probably tumor necrosis factor, that kills neighboring oligodendrocytes (Robbins et al., 1987). The current experiments show that neonatal white matter astrocytes are far more sensitive to ischemic injury than are axons at the same age in the same tissue (Fern et al., 1998). In this white matter tract astrocyte injury therefore represents the first step in the development of functional loss. 


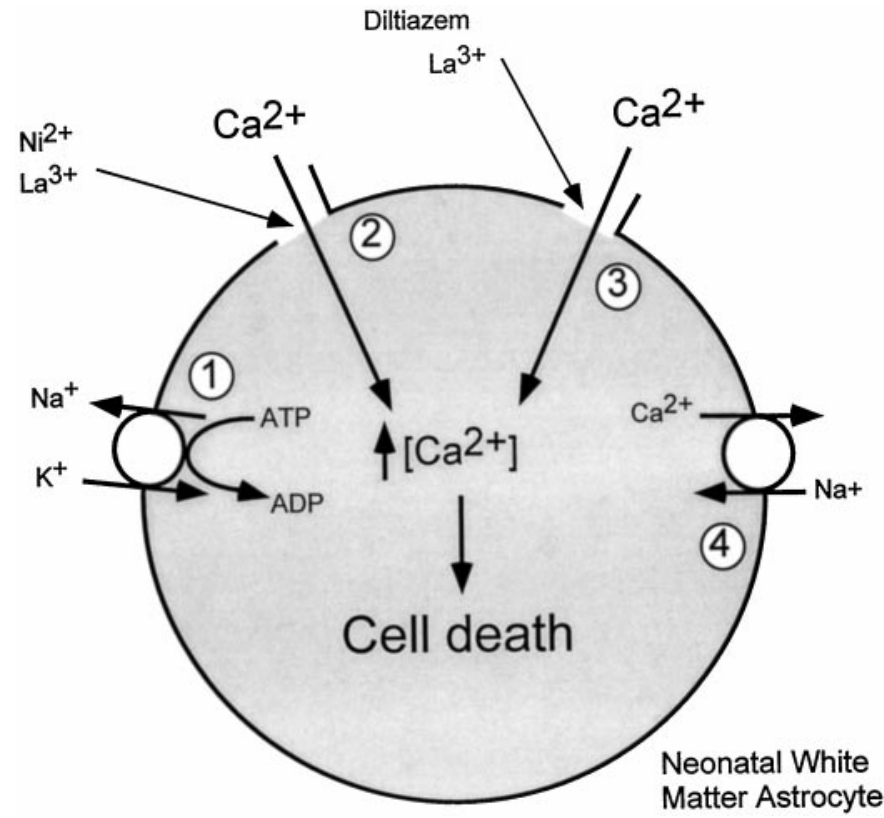

Figure 14. $\mathrm{Ca}^{2+}$ influx and cell death during ischemia in neonatal optic nerve astrocytes. Ischemia is followed by a drop in ATP and breakdown in the operation of ATP-dependent membrane transport proteins (1). The resulting membrane depolarization activates $\mathrm{Ni}^{2+}{ }_{-}$and $\mathrm{La}^{3+}$ sensitive voltage-gated $\mathrm{Ca}^{2+}$ channels (2; apparently T-type channels). T-type channel-mediated $\mathrm{Ca}^{2+}$ influx is transitory, and $\left[\mathrm{Ca}^{2+}\right]_{\mathrm{i}}$ may recover because of the action of the $\mathrm{Na}^{+}-\mathrm{Ca}^{2+}$ exchanger (4). There is a subsequent $\mathrm{Ca}^{2+}$ influx mediated by L-type $\mathrm{Ca}^{2+}$ channels (3). Increased $\left[\mathrm{Ca}^{2+}\right]_{\mathrm{i}}$ resulting from $\mathrm{Ca}^{2+}$ influx through voltage-gated channels is associated with cell death.

\section{REFERENCES}

Banker BQ, Larroche J-C (1962) Periventricular leukomalacia of infancy: a form of neonatal anoxic encephalopathy. Arch Neurol 7:386-410.

Barres BA, Chun LL, Corey DP (1989) Calcium current in cortical astrocytes: induction by cAMP and neurotransmitters and permissive effect of serum factors. J Neurosci 9:3169-3175.

Barres BA, Koroshetz WJ, Chun LL, Corey DP (1990) Ion channel expression by white matter glia: the type-1 astrocyte. Neuron 5:527-544.

Bevensee MO, Schwiening CJ, Boron WF (1995) Use of BCECF and propidium iodide to assess membrane integrity of acutely isolated CA1 neurons from rat hippocampus. J Neurosci Methods 58:61-75.

Butt AM, Ransom BR (1993) Morphology of astrocytes and oligodendrocytes during development in the intact rat optic nerve. J Comp Neurol 338:141-158.

Choi DW (1988) Calcium-mediated neurotoxicity: relationship to specific channel types and role in ischemic damage. Trends Neurosci 11:465-469.

Corvalan V, Cole R, De Vellis J, Hagiwara S (1990) Neuronal modulation of calcium channel activity in cultured rat astrocytes. Proc Natl Acad Sci USA 87:4345-4348.

DeReuck J, Chattha AS, Richardson EPJ (1972) Pathogenesis and evolution of periventricular leukomalacia in infancy. Arch Neurol 27:229-236.

Dubinsky JM, Rothman SM (1991) Intracellular calcium concentrations during "chemical hypoxia" and excitotoxic neuronal injury. J Neurosci 11:2545-2551.

Duchen MR, Valdeolmillos M, O'Neill SC, Eisner DA (1990) Effects of metabolic blockade on the regulation of intracellular calcium in dissociated mouse sensory neurones. J Physiol (Lond) 424:411-426.

Duffy S, MacVicar BA (1996) In vitro ischemia promotes calcium influx and intracellular calcium release in hippocampal astrocytes. J Neurosci 16:71-81.

Fern R, Davis P, Waxman SG, Ransom BR (1998) Axon conduction and survival in CNS white matter during energy deprivation: a developmental study. J Neurophysiol 79:95-105.
Fox AP, Nowycky MC, Tsien RW (1987) Kinetic and pharmacological properties distinguishing three types of calcium currents in chick sensory neurones. J Physiol (Lond) 394:149-172.

Friedman JE, Haddad GG (1993) Major differences in $\left[\mathrm{Ca}^{2+}\right]_{\mathrm{i}}$ response to anoxia between neonatal and adult rat CA1 neurons: role of $\left[\mathrm{Ca}^{2+}\right]_{0}$ and $\left[\mathrm{Na}^{+}\right]_{\mathrm{o}}$. J Neurosci 13:63-72.

Gallo V, Russell JT (1995) Excitatory amino acid receptors in glia: different subtypes for distinct functions? J Neurosci Res 42:1-8.

Geeraerts MD, Ronveaux Dupal MF, Lemasters JJ, Herman B (1991) Cytosolic free $\mathrm{Ca}^{2+}$ and proteolysis in lethal oxidative injury in endothelial cells. Am J Physiol 261:C889-C896.

Gilles FH, Murphy SF (1969) Perinatal telencephalic leucoencephalopathy. J Neurol Neurosurg Psychiatry 32:404-413.

Goldman WF, Yarowsky PJ, Juhaszova M, Krueger BK, Blaustein MP (1994) Sodium/calcium exchange in rat cortical astrocytes. J Neurosci 14:5834-5843.

Grynkiewicz G, Poenie M, Tsien RY (1985) A new generation of $\mathrm{Ca}^{2+}$ indicators with greatly improved fluorescence properties. J Biol Chem 260:3440-3450.

Hasham MI, Naumann D, Kim SU, Cashman NR, Quamme GA, Krieger C (1994) Intracellular calcium concentrations during metabolic inhibition in the motoneuron cell line NSC-19. Can J Physiol Pharmacol 72:728-737.

Haugland RP (1996) Handbook of fluorescent probes and research chemicals. Eugene, OR: Molecular Probes.

Haun SE, Murphy EJ, Bates CM, Horrocks LA (1992) Extracellular calcium is a mediator of astroglial injury during combined glucoseoxygen deprivation. Brain Res 593:45-50.

Hille B (1992) Ionic channels of excitable membranes. Sunderland, MA: Sinauer.

Johnson ME, Gores GJ, Uhl CB, Sill JC (1994) Cytosolic free calcium and cell death during metabolic inhibition in a neuronal cell line. J Neurosci 14:4040-4049.

Kaczorowski GJ, Slaughter RS, King VF, Garcia ML (1989) Inhibitors of sodium-calcium exchange: identification and development of probes of transport activity. Biochim Biophys Acta 988:287-302.

Kriegler S, Chiu SY (1993) Calcium signaling of glial cells along mammalian axons. J Neurosci 13:4229-4245.

Kuban KC, Leviton A (1994) Cerebral palsy. N Engl J Med 330:188-195.

Lemasters JJ, DiGuiseppi J, Nieminen AL, Herman B (1987) Blebbing, free $\mathrm{Ca}^{2+}$, and mitochondrial membrane potential preceding cell death in hepatocytes. Nature 325:78-81.

Leviton A, Gilles FH (1971) Morphologic correlates of age at death of infants with perinatal telencephalic leukoencephalopathy. Am J Pathol 65:303-309.

Lobner D, Lipton P (1993) Intracellular calcium levels and calcium fluxes in the CA1 region of the rat hippocampal slice during in vitro ischemia: relationship to electrophysiological cell damage. J Neurosci 13:4861-4871.

Ochi S, Lim JY, Rand MN, During MJ, Sakatani K, Kocsis JD (1993) Transient presence of GABA in astrocytes of the developing optic nerve. Glia 9:188-198.

Oka A, Belliveau MJ, Rosenberg PA, Volpe JJ (1993) Vulnerability of oligodendroglia to glutamate: pharmacology, mechanisms, and prevention. J Neurosci 13:1441-1453.

Paneth N, Rudelli R, Kazam E, Monte W (1994) Brain damage in the preterm infant. Cambridge: Cambridge UP.

Pappas CA, Ransom BR (1995) The effect of anoxia and simulated ischemia on the viability of cultured rat hippocampal astrocytes. Soc Neurosci Abstr 21:88.1.

Porter JT, McCarthy KD (1995) GFAP-positive hippocampal astrocytes in situ respond to glutamatergic neuroligands with increases in $\left[\mathrm{Ca}^{2+}\right]_{\mathrm{i}}$. Glia 13:101-112.

Racik P (1981) Neuronal-glial interaction during brain development. Top Neurosci 4:184-197.

Robbins DS, Shirazi Y, Drysdale BE, Lieberman A, Shin HS, Shin ML (1987) Production of cytotoxic factor for oligodendrocytes by stimulated astrocytes. J Immunol 139:2593-2597.

Romijn HJ, Hofman MA, Gramsbergen A (1991) At what age is the developing cerebral cortex of the rat comparable to that of the full-term newborn human baby? Early Hum Dev 26:61-67.

Rose CR, Waxman SG, Ransom BR (1998) Effects of glucose deprivation, chemical hypoxia, and simulated ischemia on $\mathrm{Na}^{+}$homeostasis in spinal cord astrocytes. J Neurosci 18:3554-3562. 
Ryu PD, Randic M (1990) Low- and high-voltage-activated calcium currents in rat spinal dorsal horn neurons. J Neurophysiol 63:273-285.

Siesjo BK, Bengtsson F (1989) Calcium fluxes, calcium antagonists, and calcium-related pathology in brain ischemia, hypoglycemia, and spreading depression: a unifying hypothesis. J Cereb Blood Flow Metab 9:127-140.

Sontheimer H (1994) Voltage-dependent ion channels in glial cells. Glia $11: 156-172$.

Sontheimer H, Waxman SG (1993) Expression of voltage-activated ion channels by astrocytes and oligodendrocytes in the hippocampal slice. J Neurophysiol 70:1863-1873.

Stys PK, Waxman SG, Ransom BR (1992) Ionic mechanisms of anoxic injury in mammalian CNS white matter: role of $\mathrm{Na}^{+}$channels and $\mathrm{Na}^{+}-\mathrm{Ca}^{2+}$ exchanger. J Neurosci 12:430-439.
Stys PK, Sontheimer H, Ransom BR, Waxman SG (1993) Noninactivating, tetrodotoxin-sensitive $\mathrm{Na}^{+}$conductance in rat optic nerve axons. Proc Natl Acad Sci USA 90:6976-6980.

Tymianski M, Bernstein GM, Abdel Hamid KM, Sattler R, Velumian A, Carlen PL, Razavi H, Jones OT (1997) A novel use for a carbodiimide compound for the fixation of fluorescent and nonfluorescent calcium indicators in situ following physiological experiments. Cell Calcium $21: 175-183$.

Verkhratsky A, Orkand RK, Kettenmann H (1998) Glial calcium: homeostasis and signal function. Physiol Rev 78:99-141.

Volpe JJ (1995) Neurology of the newborn. Philadelphia: Saunders.

Yu AC, Gregory GA, Chan PH (1989) Hypoxia-induced dysfunctions and injury of astrocytes in primary cell cultures. J Cereb Blood Flow Metab 9:20-28. 